\title{
FORUM
}

\section{The Chemical Volatiles (Semiochemicals) Produced by Neotropical Stink Bugs (Hemiptera: Pentatomidae)}

\author{
Maria C.B. Moraes, Martín Pareja, Raúl A. Laumann and Miguel Borges
}

Núcleo Temático Controle Biológico, Embrapa Recursos Genéticos e Biotecnologia, C. postal 2372, 70849-970, Brasília, DF

Neotropical Entomology 37(5):489-505 (2008)

Os Voláteis Químicos (Semioquímicos) Produzidos pelos Percevejos Neotropicais Hemiptera: Pentatomidae)

RESUMO - Nos últimos anos tem sido crescente a preocupação com as mudanças climáticas e com a utilização auto-sustentável dos recursos naturais, estimulando cada vez mais os estudos para a prospecção de novos produtos naturais visando minimizar o uso de pesticidas. Os percevejos produzem uma variedade de compostos químicos com potencial para o seu manejo. A composição química dos compostos defensivos dos percevejos Chinavia impicticornis (Stål), C. ubica (Rolston), Dichelops melacanthus (Dallas), Euschistus heros (F.), Piezodorus guildinii (Westwod), Thyanta perditor (Westwood) e Tibraca limbativentris (Stål) foi avaliada. Os principais compostos nas glândulas dos percevejos foram: 2-alcenais, principalmente o isômero $E$, hidrocarbonetos alifáticos saturados; e 4 oxo-(E)-2-alcenal. O primeiro feromônio sexual de percevejo identificado no Brasil foi do Nezara viridula L., que consiste na mistura dos isômeros cis e trans epóxi-bisabolenos; na sequência, o percevejo praga da soja E. heros também teve seu feromônio sexual identificado. Os machos desta espécie produzem três ésteres: 2,6,10-trimetildecanoato de metila, 2,6,10 trimetildodecanoato de metila e $2 E, 4 Z$ decadienoato de metila. Recentemente, mais três espécies de percevejos neotropicais tiveram a composição da mistura feromonal elucidada. Machos de T. perditor produzem o éster, $2 E, 4 Z, 6 Z$ decatrienoato de metila. O percevejo $P$. guildinii tem como feromônio sexual o $\beta$-sesquifelandreno, e o percevejo praga do arroz $T$. limbativentris tem também como feromônio sexual um sesquiterpenóide, o zingiberenol. Nessa revisão serão abordados os avanços obtidos no estudo do comportamento e identificação de feromônios sexuais e de alarme de várias espécies do complexo de percevejos praga da agricultura brasileira. A aplicação desses conhecimentos é discutida.

PALAVRAS-CHAVE: Feromônio, aleloquímico, agregação, comportamento, soja

ABSTRACT - In recent years the growing concern about environmental changes and how we are using the natural resources have triggered a search for natural products as alternatives to synthetic pesticides. The stink bugs produce a wide variety of chemical compounds (semiochemicals) that show potential to manage these insects. The stink bugs Chinavia impicticornis (Stål), C. ubica (Rolston), Dichelops melacanthus (Dallas), Euschistus heros (F.), Piezodorus guildinii (Westwood), Thyanta perditor (Westwood) and Tibraca limbativentris (Stål) had their blends of defensive compounds evaluated both qualitative and quantitatively. The main compounds identified on the glands of Brazilian stink bugs are: 2-alkenals, mainly the $E$ isomer; saturated aliphatic hydrocarbons; and 4 oxo-(E)-2-alkenals. The first sex attractant determined from a stink bug was obtained from Nezara viridula L., and consists on a mix of two isomers cis - and trans bisabolene-epoxides. Later the soybean stink bug E. heros was also studied and its sex attractant was identified as three esters methyl : 2,6,10-trimethyldecanoate, methyl 2,6,10-trimethyldodecanoate, and methyl E2, Z4-decadienoate. Recently, three new Brazilian sting bugs were studied and had their sex attractant elucidated. Males of T. perditor produce the ester, methyl $2 E, 4 Z, 6 Z$-decatrienoate. Whereas, the stink bug, $P$. guildinii has as sexual pheromone, the sesquiterpene $\beta$-sesquiphellandrene, and the stink bug $T$. limbativentris produces as sex attractant the zingiberenol. In this review we discuss the advances obtained on the behaviour and identification of sex and defensive compound of stink bugs from Brazilian crops and the application of this knowledge to manage the stink bugs.

KEY WORDS: Pheromone, allelochemical, aggregation, behaviour, soybean 
In recent years there has been a growing concern about environmental changes, and about how we are using the resources available in natural habitats. These concerns have triggered a search for natural products as a source of medicines, cosmetics, fuel, nutrients for humans and animals, and, especially, as alternatives to synthetic pesticides. In turn this has led to an awareness of the importance of studying natural products, and of conserving the natural habitats that remain largely unexplored in the tropics and subtropics.

Brazil, nowadays, is one of the largest producers and exporters of soybean and other crops in the world (CONAB 2007). However, millions of tonnes of grains and products are lost every year due to damage by pests, mainly due to various Pentatomidae (stink bugs) and Lepidoptera (Panizzi 1997).

The stink bugs produce a wide variety of chemical compounds that show potential to manage these insects. Among these compounds are the pheromones, which can be classified as either sexual, alarm or aggregation pheromones (Aldrich 1988). Stink-bug management by the use of semiochemicals is an alternative that has shown potential for application in soybean and others crops (Aldrich 1988; Borges et al. 1998a, b).

Semiochemicals mediate interactions of insects with other organisms and they can be used to directly monitor populations, mass trap pests or interfere with reproduction by sexual confusion. Indirect applications include manipulation of the natural enemies, such as parasitic wasps, for instance, that use both sex pheromones and defensive compounds during their foraging behaviour (Vinson 1985, Borges et al. 1998a, Bruni et al. 2000, Fiaboe et al. 2003).

In this review we report on identifications of the main semiochemicals from Brazilian stink bugs populations, illustrating the diversity of the compounds, the currents methods used for extraction and identification and the possibilities of using these compounds in pest control.

\section{Defensive Compounds, Aggregation Pheromones and Alarm Pheromones}

Pentatomids produce a mixture of chemical compounds that serve as both alarm pheromones and defence against predators, so it is important to understand the difference between defensive compounds and alarm pheromones. In the literature semiochemicals can be separated into pheromones and allelochemicals (Dicke \& Sabelis 1988). Pheromones are chemical compounds that mediate interactions between individuals of the same species, and allelochemicals are chemical compounds that mediate interactions between individuals of different species. Within the allelochemicals there are three classes, depending on the interaction between the organisms involved: if the chemical mediates an interaction that provides a selective advantage to the emitter (e.g. an irritant that deters a predator), it is referred to as an allomone; if the selective advantage is to the receiver (e.g. when a predator uses a pentatomid smell to locate its prey) it is referred to as a kairomone; if both organisms receive selective advantage (e.g. herbivore damaged plant elicit volatiles that attracts an insect that kills an herbivore), it is referred to as a synomone. It is important to note that these definitions are context-dependent (Dicke \& Sabelis 1988). Thus a compound can be involved in one interaction as an allomone, while in an interaction with a different organism it may be a kairomone. Here we use the term defensive compound to refer to semiochemicals produced by pentatomids that serve as allomones, or to those whose biological importance is still unknown. We use the term alarm pheromone for compounds that were shown to induce defensive behaviour (mainly dispersal and increased activity) in individuals of the same species.

The Pentatomidae are well known for producing blends of odoriferous compounds that serve mainly to directly deter predation, warn relatives of impending danger and alarm pheromones. The stink bugs produce these compounds in two different types of glands depending on their life stage (Aldrich 1988): the adults produce these compounds in the metathoracic scent glands (MTG), while nymphs produce them in the dorsal abdominal scent glands (DGAs), these glands can be retained in some Pentatomid adults as functional glands (Aldrich 1988, Aldrich et al. 1995).

The most commonly used method for extracting compounds produced in the MTG and DAGs is direct extraction of gland contents. The adult insects can be pinned through the thorax with the dorsal side up, the edges of the abdominal cuticle and the cuticle at the junction between the thorax and abdomen are cut with dissection scissors. The viscera are then removed, revealing the big orange metathoracic gland (MTG). The gland is pierced with a flamestretched glass capillary, causing the contents to rise through the capillary. The contents can be then emptied into solvent by immersing the tip of the capillary into the solvent and briefly passing charcoal-filtered air through the capillary (Pareja et al. 2007). The standard method of extraction of defensive compounds from the DAG of nymphs is by immersing the exuviae of nymphs in solvent shortly after moulting. This methodology was developed by Borges \& Aldrich (1992) and, provided the exuviae are collected soon after moulting, a single moult of a fifth-instar nymph is enough to obtain analysable quantities of defensive compounds. For earlier instars several exuviae are sometimes needed. This method works because the DAG contents are shed along with the exuviae when the nymphs moult. Collection of volatiles by aeration is also a common method used, but is less likely to adequately sample minor constituents.

The semiochemicals obtained, in general, are analysed by gas-chromatography (GC) and GC coupled to mass spectrometry (GC-MS) for quantitative and qualitative analysis. These methodologies are not specific to Pentatomidae, and can be found in recent reviews and books on analysis of semiochemicals (Millar \& Haynes 2000, Vilela \& Dela Lucia 2001)

There are several studies detailing the qualitative differences in the blends produced by nymphs and adults (Lusby \& Kochansky 1986, Aldrich \& Yonke 1975, Borges \& Aldrich 1992, Farine et al. 1992, Blatt et al. 1998), and between males and females (Aldrich et al. 1993a, Ho et al. 2003). More recently Pareja et al. (2007) conducted a study showing qualitative and quantitative differences of the defensive compounds on five different species of Pentatomidae found in Brazil. 
The stink bugs Chinavia impicticornis (Stål), Chinavia ubica (Rolston), Dichelops melacanthus (Dallas), Euschistus heros (F.) and Piezodorus guildinii (Westwood) have had their blends of defensive compounds evaluated both qualitative and quantitatively (Table 1). All these studies showed that the blends of defensive compounds are species-specific.

Table 1. Defensive compounds and alarm pheromones identified on Neotropical estink bugs captured in Brazil: Ci Chinavia impicticornis; Cu - Chinavia ubica; Dm - Dichelops melacanthus; Eh - Euschistus heros; Nv - Nezara viridula; Pg - Piezodorus guildinii; Tl - Tibraca limbativentris; Tp - Thyanta perditor. List based on studies from Aldrich et al. (1978), Lockwood \& Story (1987), Borges \& Aldrich (1992), Zarbin et al. (2000), Fucarino et al. (2004), Moraes et al. (2005), Borges et al. (2006) and Pareja et al. (2007).

\begin{tabular}{|c|c|c|c|}
\hline Compound & Structure & Masss spectra & Species \\
\hline \multicolumn{4}{|l|}{ Aldehydes } \\
\hline Hexanal & & $\begin{array}{l}82\left(\mathrm{M}^{+}, 20\right), 72(26), 67(17), 56(90) \\
44(100)\end{array}$ & $\mathrm{Ci}, \mathrm{Pg}, \mathrm{Nv}$ \\
\hline (E)-2-Hexenal & & $\begin{array}{l}98\left(\mathrm{M}^{+}, 14\right), 83(46), 69(72) \\
41(100), 55(70)\end{array}$ & $\begin{array}{l}\mathrm{Ci}, \mathrm{Cu}, \mathrm{Dm}, \mathrm{Eh}, \\
\mathrm{Nv}, \mathrm{Pg}\end{array}$ \\
\hline (Z)-2-Octenal & & $\begin{array}{l}126(1) 112(6), 97(19), \\
83(100), 70(81), 55(77), 41(68)\end{array}$ & $\mathrm{Dm}, \mathrm{Eh}$ \\
\hline (E)-2-Octenal & & $\begin{array}{l}108(1), 97(11), 83(47), 82 \\
(27), 70(82), 69(42), 57(56), 55 \\
(88), 41(100)\end{array}$ & $\begin{array}{l}\mathrm{Ci}, \mathrm{Cu}, \mathrm{Dm}, \mathrm{Eh}, \\
\mathrm{Nv}, \mathrm{Pg}, \mathrm{Tl}, \mathrm{Tp}\end{array}$ \\
\hline Nonanal & & $\begin{array}{l}124(>1), 98(31), 95(22), 83(33) \\
70(50), 57(100) 41(90)\end{array}$ & $\mathrm{Ci}, \mathrm{Pg}, \mathrm{Tl}, \mathrm{Tp}$ \\
\hline (E)-2-Nonenal & & $\begin{array}{l}41(100), 70(100), 43(98), 55(92), 83( \\
73), 96(38), 111(25)\end{array}$ & $\mathrm{Cu}, \mathrm{Dm}$ \\
\hline Decanal & & $\begin{array}{l}\text { 128(3), 112(20), 110(15), 96(21), } \\
95(23), 82(46), 70(58), 43(100), \\
57(95)\end{array}$ & $\mathrm{Tl}$ \\
\hline (Z)-2-Decenal & & $\begin{array}{l}136(2), 121(2), 110(20), 97(9) \\
83(82), 70(100), 55(51), 41(48)\end{array}$ & $\mathrm{Ci}, \mathrm{Cu}, \mathrm{Nv}$ \\
\hline (E)-2-Decenal & & $\begin{array}{l}\left.\text { 154(M } \mathrm{M}^{+},<1\right), 121(4), 136(4) \\
110(12), 98(18), 83(46), 70(90) \\
55(72), 43(100), 41(88)\end{array}$ & $\begin{array}{l}\mathrm{Ci}, \mathrm{Cu}, \mathrm{Dm}, \mathrm{Eh}, \\
\mathrm{Nv}, \mathrm{Tp}\end{array}$ \\
\hline$(E, Z)-2,4$-Decadienal & & $\begin{array}{l}152\left(\mathrm{M}^{+}, 5\right) 123(5), 108(4), 95(15), \\
81(100), 67(24), 55(16), 41(31)\end{array}$ & $\mathrm{Ci}, \mathrm{Cu}, \mathrm{Dm}, \mathrm{Eh}$ \\
\hline$(E, E)-2,4$-Decadienal & & $\begin{array}{l}152\left(\mathrm{M}^{+}, 2\right), 81(100), 95(15) \\
73(27), 67(22), 55(10), 41(21)\end{array}$ & $\mathrm{Ci}, \mathrm{Cu}, \mathrm{Eh}$ \\
\hline Tridecanal & & $\begin{array}{l}180\left(\mathrm{M}^{+}, 2\right), 154(5), 124(28) \\
110(14), 109(24), 96(47), 82(73) \\
67(58), 57(100), 43(77)\end{array}$ & $\mathrm{Cu}$ \\
\hline Tetradecanal & & 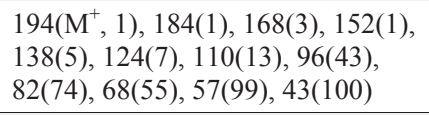 & $\mathrm{Cu}, \mathrm{Dm}, \mathrm{Eh}, \mathrm{Pg}$ \\
\hline \multicolumn{4}{|c|}{ ( } \\
\hline Hexyl acetate & & $\begin{array}{l}101(2), 84(18), 73(17), 69(22) \\
61(25), 56(52), 43(100)\end{array}$ & $\mathrm{Ci}$ \\
\hline (E)-2-Hexenyl acetate & & $\begin{array}{l}142\left(\mathrm{M}^{+},<1\right), 113(1), 100(16), \\
43(100), 82(26), 71(7), 67(40), \\
55(15)\end{array}$ & $\mathrm{Ci}, \mathrm{Cu}, \mathrm{Eh}, \mathrm{Nv}$ \\
\hline (E)-2-Hexenyl butyrate & & $\begin{array}{l}100(2), 83(10), 82(24), 71(100) \\
67(20), 43(47), 55(30)\end{array}$ & $\mathrm{Cu}, \mathrm{Eh}, \mathrm{Nv}$ \\
\hline (E)-2-Octenyl-acetate & & $\begin{array}{l}128\left(\mathrm{M}^{+}, 6\right), 110(9), 95(7), 81(20) \\
68(20), 67(21), 54(30), 43(100)\end{array}$ & $\mathrm{Ci}, \mathrm{Cu}, \mathrm{Dm}, \mathrm{Eh}$ \\
\hline
\end{tabular}


Table 1. Continuation.

\begin{tabular}{|c|c|c|c|}
\hline Compound & Structure & Masss spectra & Species \\
\hline (E)-2-Decenyl acetate & & $\begin{array}{l}156\left(\mathrm{M}^{+}, 6\right), 127(2), 138(4), \\
110(11), 96(17), 81(19), 67(23), \\
54(29), 43(100)\end{array}$ & $\begin{array}{l}\mathrm{Ci}, \mathrm{Cu}, \mathrm{Dm}, \mathrm{Eh}, \\
\mathrm{Nv}\end{array}$ \\
\hline \multicolumn{4}{|l|}{ Alcohols } \\
\hline Hexan-1-ol & & $56(100), 43(60), 69(36), 84(5)$ & $\mathrm{Ci}, \mathrm{Nv}$ \\
\hline (E)-2-Octen-1-ol & & $\begin{array}{l}110\left(\mathrm{M}^{+}, 4\right), 95(8), 81(21), 68(27), \\
57(100), 41(53)\end{array}$ & $\mathrm{Eh}, \mathrm{Tp}$ \\
\hline Tridecan-1-ol* & & $\begin{array}{l}\left.\text { 154(M } \mathrm{M}^{+}, 4\right), 125(14), 111(30) \\
97(51), 83(80), 69(96), 55(100), \\
43(81)\end{array}$ & $\mathrm{Ci}$ \\
\hline \multicolumn{4}{|l|}{ Monterpenoids } \\
\hline$\alpha$-Pinene & & $\begin{array}{l}\left.\text { 136(M } \mathrm{M}^{+}, 6\right), 121(10), 105(10), 93 \\
(100), 92(38), 91(39), 79(23), 77 \\
(28), 69(<1), 67(10), 53(7), 41 \\
(15)\end{array}$ & $\mathrm{Tl}$ \\
\hline$\beta$-Pinene & & $\begin{array}{l}136\left(\mathrm{M}^{+}, 7\right), 121(10), 105(3), 94 \\
(4), 93(100), 92(11), 91(26), 80 \\
(12), 79(23), 77(23), 69(38), 53 \\
(8), 41(44)\end{array}$ & $\mathrm{Tl}, \mathrm{Tp}$ \\
\hline$\alpha$-Ocimene* & & $\begin{array}{l}136\left(\mathrm{M}^{+}, 6\right), 121(15), 105(13), \\
93(100), 91(29), 80(39), 79(40), \\
77(34), 67(17), 55(26), 53(28), \\
51(13), 43(36), 41(68)\end{array}$ & $\mathrm{Tp}$ \\
\hline Limonene & & $\begin{array}{l}\left.\text { 136( } \mathrm{M}^{+}, 12\right), 121(21), 107(19) \\
94(34), 93(62), 79(33) \\
68(100), 67(84), 53(22)\end{array}$ & $\mathrm{Ci}, \mathrm{Eh}, \mathrm{Tl}$ \\
\hline Linalool & & $\begin{array}{l}\left.\text { 136(M } \mathrm{M}^{+}, 4\right), 107(5), 121(14), \\
93(64), 80(30), 71(100), 43(65), \\
41(64)\end{array}$ & Eh \\
\hline
\end{tabular}

\section{Sesquiterpenoids}

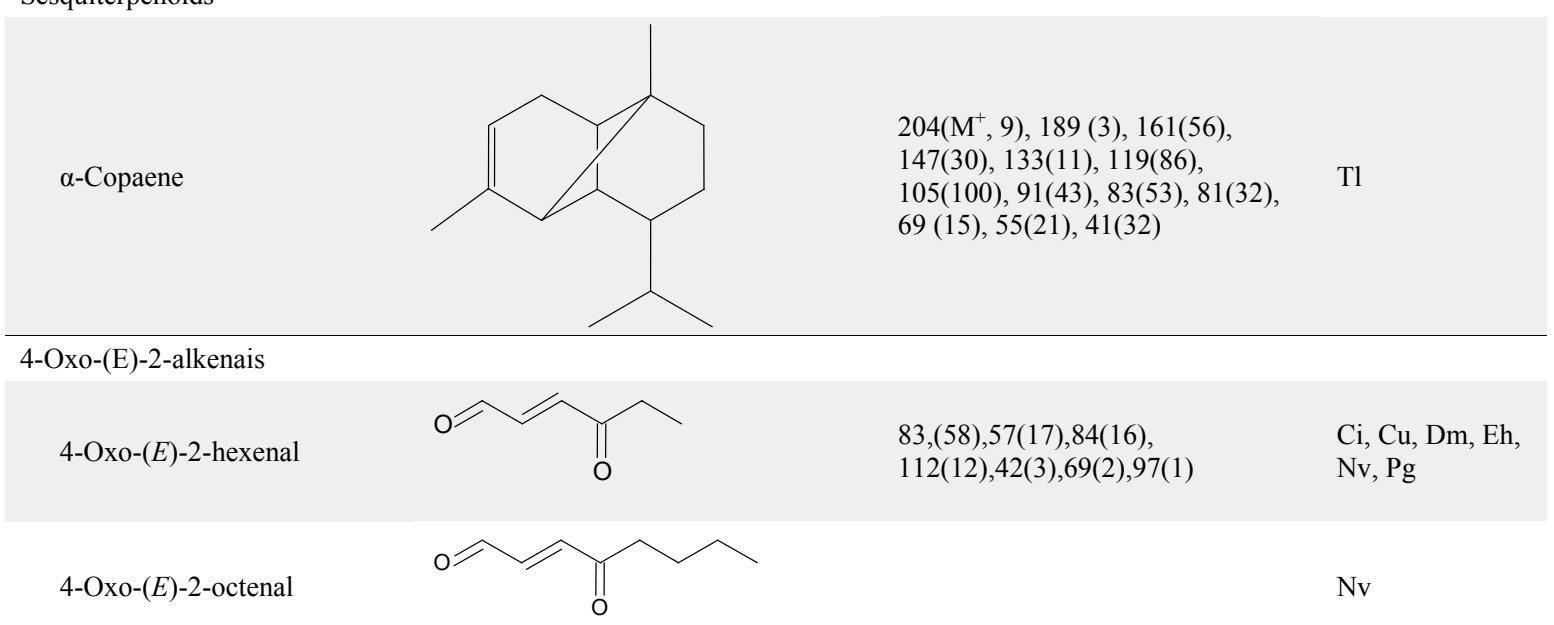


Table 1. Continuation.

\begin{tabular}{llll}
\hline Compound & \multicolumn{1}{c}{ Masss spectra } & \multicolumn{1}{c}{ Species } \\
\hline 4-Oxo-(E)-2-decenal & $\begin{array}{l}55(100), 43(97), 98(80), 70(70), 83(6 \\
2), 139(53), 41(60), 125(22), 111(17)\end{array}$ & $\mathrm{Ci}, \mathrm{Eh}, \mathrm{Nv}$ \\
$\begin{array}{l}\text { 4-Hydroxy-4-methyl- } \\
\text { pentanone }\end{array}$ & $\begin{array}{l}43,59(53), 101(16), 83(3), \\
69(<1)\end{array}$ & $\begin{array}{l}\mathrm{Ci}, \mathrm{Cu}, \mathrm{Dm}, \mathrm{Eh}, \\
\mathrm{Pg}\end{array}$ \\
6-Methyl-5-hepten-2-one & $\begin{array}{l}126\left(\mathrm{M}^{+}, 4\right), 111(12), 108(35), \\
93(14), 69(38), 58(17), 55(38), 43 \\
(100), 41(55)\end{array}$ & $\mathrm{Tl}$ \\
\hline
\end{tabular}

On the other hand, different species may have exactly the same compounds in the blend, but these compounds are in different ratios.

This specificity can potentially play an important role in intra-specific communication and may help to understand the phylogeny of some pentatomid groups, and to understand the evolution of insect defence. For example the sister species, C. impicticornis and C. ubica are more similar to each other than the species E. heros, $P$. guildinii and D. melacanthus (Fig. 1) (Pareja et al. 2007).

The defensive compounds have simple chemical structures when compared with the sex pheromones produced by these insects, making their identification straight forward.
Although some chromatographic and spectrometric data are not yet available (as for some of the 4-oxo-(E)-2-alkenals), we present spectra obtained for these compounds (Table 1).

The main compounds identified from the glands of Brazilian stink bugs are: 2-alkenals (aldehydes with an unsaturation at the second-third carbons), mainly the $E$-isomer with very small quantities of the $Z$ - isomer; saturated aliphatic hydrocarbons; and 4-oxo- $(E)$-2-alkenals $\left(\mathrm{C}_{6}, \mathrm{C}_{8}\right.$ and $\left.\mathrm{C}_{10}\right)$. Esters, alcohols and unsaturated hydrocarbons are present as well, but in lower quantities and in some species, such as for the males of $P$. guildinii, various sesquiterpenes occur (Borges et al. 2007a). The 4-oxo-alkenals are present in higher quantities in nymphs of the pentatomids when compared with

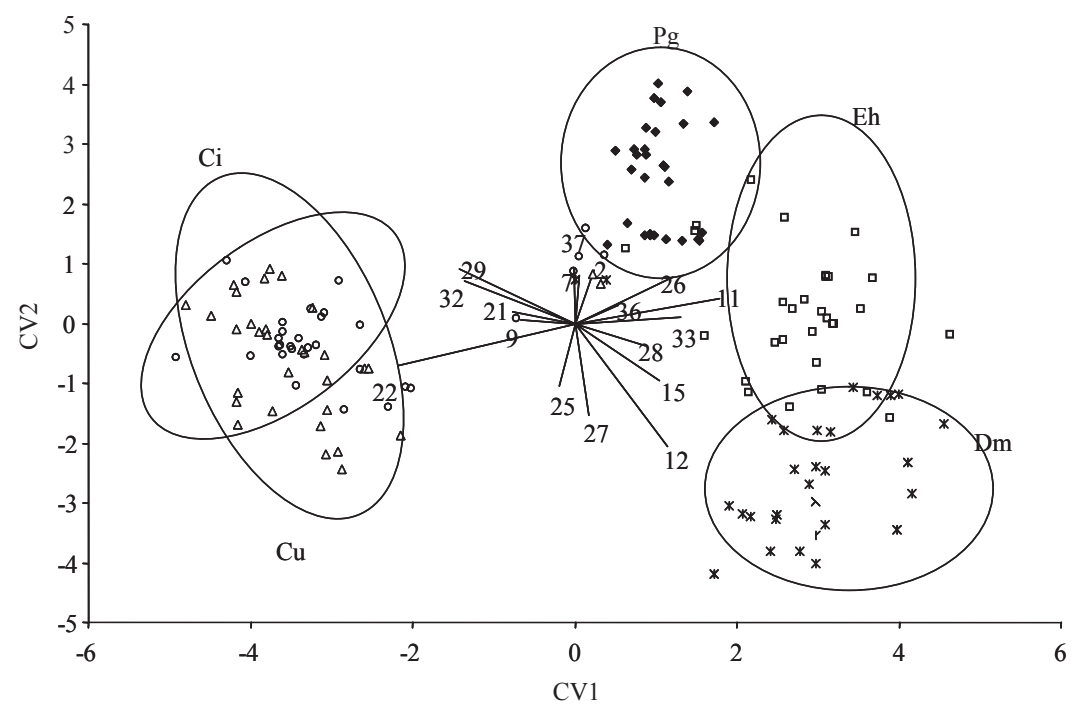

Fig. 1. Canonical variates analysis (CVA) biplot for A) the analysis differentiating between species. The points are the individual scores for each replicate, calculated from the CVA equation that maximises differences between treatments along the two dimensions defined by the two canonical variates (CV1 and CV2). The lines are the loadings for each of the variates (compounds), and the length of the line represents the relative magnitude of the importance of each compound in differentiating between treatments in the two dimensions. For A) only the first two canonical variates (representing $85 \%$ of the variability) are presented out of the four possible canonical variates. 2. 4-Hydroxy-4-methyl-pentanone; 7. Decane; 9. (E)-2-Hexenyl acetate; 11. (Z)-2-Octenal; 12. (E)-2-Octenal; 14. Undecane; 15. Linalool; 21. (Z)-2-Decenal; 22. (E)-2-Decenal; 23. 1-Tridecene; 25. Tridecane; 26. (E,E)-2,4Decadienal; 27. 4-Oxo-(E)-2-decenal; 28. Unknown 2; 29. Tetradecene; 32. Unknown 3; 33. Pentadecene; 36. Tetradecanal; 37. Tridecan-1-ol. 
MTG of adult insects (Aldrich 1988). These compounds were responsible for separating nymphal blends from adult blends of Neotropical pentatomids (Pareja et al. 2007).

The biological role of most of these defensive compounds still needs to be studied. Three of the compounds that were identified in higher concentrations in Brazilian species, namely $(E)$-2-octenal, $(E)$-2-decenal and $(E)$-2-hexenal, were reported initially as defensive compounds (Gilby \& Waterhouse 1967) and later as alarm pheromones (Lockwood \& Story 1987, Pavis 1994). In addition, some of these compounds are used as kairomones by natural enemies. For example, the egg parasitoid Telenomus podisi uses (E)-2-hexenal as a cue to find its preferred host, E. heros. This compound has been tested in bioassays using a Y-tube olfactometer and in the field (Peres 2004; Laumann et al., unpublished). However $(E)$-2-hexenal is a common plant volatile, and is produced in large amounts by soybean, a major host plant for E. heros (Moraes et al. 2008a). Thus it is not yet possible to determine whether the parasitoid responds to this compound as a cue directly associated to their host or as a means of finding the habitat of their host. These aldehydes have also been shown to have important anti-microbial action, in particular against the entomopathogenic fungus Metarhizium anisopliae (Borges et al. 1993). These blends could therefore be important in determining susceptibility of these insects to pathogens, a consideration of likely importance in biological control efforts.

The esters, although in lower concentrations than the aldehydes have also been shown to have biological importance, mainly as an alarm pheromone in $N$. viridula (Lockwood \& Story 1987).

The aliphatic hydrocarbons are present in large quantities, and in most species tridecane is one of the principal compounds found in gland or aeration extracts (Aldrich et al. 1989, 1994; Moraes et al. 2005a; Borges et al. 2007a; Pareja et al. 2007). However, in Edessa rufomarginata (Howard \& Wiemer 1983) and Edessa meditabunda (Moraes et al, unpublished data) undecane is the most abundant aliphatic hydrocarbon. Lockwood \& Story (1985) found that tridecane has an action as both an aggregation and an alarm pheromone for $N$. viridula, in a dose-dependent manner, though recently, Fucarino et al. (2004) did not find any biological activity for tridecane in N. viridula. Lockwood \& Story (1985) only found effects at very high (alarm) and very low (aggregation) concentrations. It is difficult to determine whether these concentrations are biologically relevant, or those used by Fucarino et al. (2004) are more realistic, since very high amounts (up to $1 \mathrm{mg}$ ) of tridecane can be present in the MTG at any given time. However the aggregation effect at very low concentrations showed that these insects can detect the compound in small amounts and this is likely to be a true aggregation effect. Aldrich (1988) proposed that one of the functions of the aliphatic hydrocarbons is to serve as solvents that modulate the evaporation of the other compounds, and this can explain the high quantities of these compounds found in extracts of the stink bugs.

The 4-oxo-(E)-2-alkenals are compounds that have only been reported in the true bugs (Suborder Heteroptera). Borges \& Aldrich (1992) identified significant quantities 4-oxo- $(E)$-2-alkenals in different instars of pentatomid mainly (E)-4-oxo-decenal on the first-instar nymphs, and the authors have postulated that this compound could play a role as an aggregation pheromone. Later Fucarino et al. (2004) showed that 4-oxo-(E)-2-decenal elicits aggregation behaviour in first-instar nymphs of $N$. viridula, as had been proposed by Borges \& Aldrich (1992). However, there is no further information on the biological activity of these compounds, since they are unique to these species, and therefore difficult to obtain. Compounds with very similar mass spectra to, and eluting just after 4-oxo-(E)-2-hexenal have been detected in Pentatomidae (Pareja et al. 2007) and others Heteroptera (Drijfhout et al. 2002). However, it is not yet clear whether these are produced by the insects or are breakdown or rearrangements of 4-oxo- $(E)$-2-hexenal.

\section{Sex Pheromones}

The Pentatomidae show a fantastic variety in the chemical structure of the few sex pheromones identified so far. In contrast to the Lepidoptera, the Pentatomidae do not show a structural pattern of the compounds following families or subfamilies. For Lepidoptera it is possible to classify the pheromones into either type I (75\%), which are long, straight chain $\left(\mathrm{C}_{10}-\mathrm{C}_{18}\right)$ alcohols and their derivatives, mainly acetates and aldehydes; type II (15\%), which are polyunsaturated hydrocarbons and their epoxy derivatives with a longer straight chain $\left(\mathrm{C}_{17}-\mathrm{C}_{23}\right)$; or miscellaneous $(10 \%)$ (Ando et al. 2004). However, for some species of Pentatomidae it is possible to observe a characteristic structural pattern at the genus level.

So far all the studies with stink bugs have detected the male as the producer of the sex pheromone (McBrien \& Millar 1999, Moraes et al. 2005a, Borges et al. 2006, Borges et al. 2007a). On the other hand, females are responsible for emitting substrate-borne vibratory signals that attract males during initial courtship and males respond to this by emitting a song that would bring together the partners for matting purpose (Čokl et al. 2000, Moraes et al. 2005b).

\section{Species of Nezara Group}

The Nezara group includes more of 100 species within eight genera, and they are cosmopolitan with higher diversity in Afrotropical and Neotropical regions. Schwertner (2005) conduced a new cladistic study of this group considering Chinavia a valid genus that includes Afrotropical, Neartic and Neotropical species formerly classified as Acrosternum. Following this new classification, all Acrosternum from the regions cited above will be refereed as Chinavia in this text (Table 3).

Of the species within the genera Nezara and Chinavia studied from different geographic areas in the world, the major components identified were: trans-(Z)-bisabolene

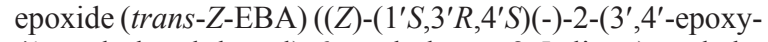
$4^{\prime}$-methylcyclohexyl)-6-methyhepta-2,5-diene) and the corresponding cis-isomer (cis-Z-EBA) (Fig. 2) (Baker et al. 1987; Aldrich et al. 1987,1993 b; McBrien et al. 2001). The trans and cis designations refer to the position between the epoxide and the pendant group on the ring. These studies 


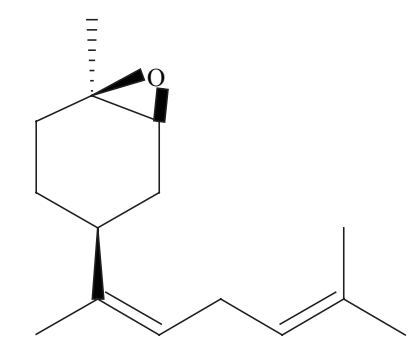

cis-(Z)-Bisabolene-epoxide (cis-Z-EBA)

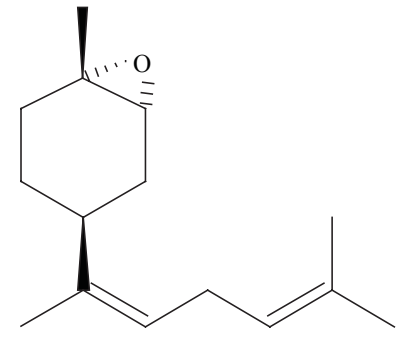

trans-(Z)-Bisabolene-epoxide (trans-Z-EBA)

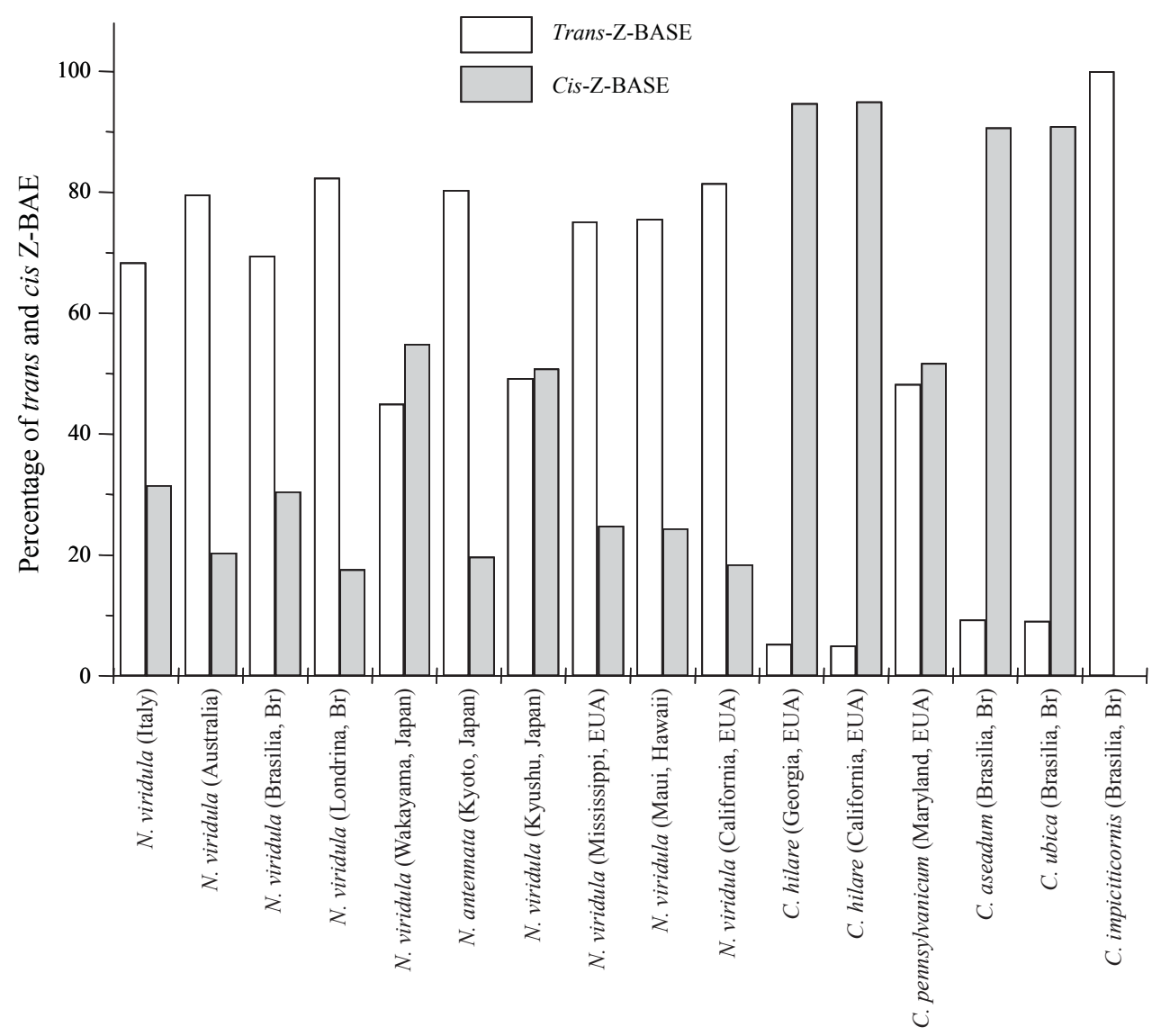

Fig. 2. Percentage of trans and cis-bisabolene-epoxide (trans and cis Z-BAE) produced by males of Nezara and Chinavia spp. from different geographic areas around the world.

showed that the specificity is guaranteed by the different ratios of the two components produced by the different species (Fig. 2) (Aldrich et al. 1989, 1993b; McBrien et al. 2001; MCB Moraes, RA Laumann \& M Borges, unpublished data). Miklas et al. (2000) using solid phase micro-extraction (SPME) methodology with $N$. viridula from different parts of the world reported that there is a great variability in the quantities of the sex pheromones produced between males of the same species, but the ratio of cis to trans-Z-EBA is constant within each strain of $N$. viridula.

Only two species in the genus Nezara, $N$. antennata and
$N$. viridula, had their sex pheromones identified, but nine $N$. viridula populations were studied from different geographical areas. All of these populations showed the trans isomer in higher quantities than the $c i$ isomer. In contrast to the Nezara species, the Chinavia species presented higher quantities of the isomer cis-Z-EBA. The exceptions are C. pennsylvanica, which produces nearly equal amounts of the isomers, and $C$. impicticornis, which only produces the trans isomer (MCB Moraes, RA Laumann \& M Borges, unpublished data). Thus C. impicticornis has a ratio between the components more similar to the blend identified for Nezara spp. than other 
Chinavia species.

The function of the ratio of trans to cis-Z-EBA is still unclear. Aldrich et al. (1989) reported that in laboratory experiments males of $N$. viridula from Japan mated with females of $N$. viridula from the USA (Mississippi), and the offspring were fertile and produced a ratio of trans to cis-Z-EBA of 1.53, which is intermediate between the two parental blends.

Bioassays in the laboratory carried out with $N$. viridula from Brasilia, Brazil, showed that females were attracted only to synthetic EBA when both isomers are present in the correct ratio (Borges 1995). The absolute configuration was identified as being ( $\left.1^{\prime} S, 3^{\prime} R, 4^{\prime} S\right)$ (1) (Baker et al. 1987), and later Borges (1995) reported that females did not show the same level of response (attraction) to the racemic mixture as to the $\left(1^{\prime} S, 3^{\prime} R, 4^{\prime} S\right)$ enantiomer. A similar result was obtained by McBrien et al. (2001) working with Chinavia hilaris Say. Females of C. hilaris responded only to the pheromonal mixture containing both cis and trans-Z-EBA in the same ratio released by the males, additionally the absolute configuration identified for this species was the same as found by Baker et al. (1987).

There is a third component that is produced only by males of Chinavia and Nezara species, which is the $(Z)-\alpha$ bisabolene (Aldrich et al. 1989, 1993b; McBrien et al. 2001). However, bioassays conducted with $(Z)$ - $\alpha$-bisabolene with C. hilaris did not provide any evidence that this compound has biological activity, and there was no evidence regarding its biological activity in other studies (Aldrich et al. 1993b, Borges 1997). McBrien et al. (2001) proposed that because of its great structural resemblance [including the $(4 S)$ configuration] with the EBA, the bisabolene could be a precursor to the pheromone components.

\section{Euschistus heros}

The pheromone components of E. heros were identified by Borges \& Aldrich (1994) and Aldrich et al. (1994) and consists of three components: methyl 2,6,10-trimethyldecanoate, methyl 2,6,10-trimethyldodecanoate, and methyl 2E,4Zdecadienoate (Table 2, compounds 1, 2 and 3). Zhang et al. (2003) confirmed the ratio proposed among the three components by Borges et al. (1998a), as being: $53 \%(2 E, 4 Z)-$ methyl decadienoate, $3 \% 2,4,6$ - methyl trimethyldodecanoate and $44 \%$ methyl 2,6, 10-trimethyltridecanoate. The biological activity of the three components was confirmed in a laboratory bioassay and showed that methyl 2,6,10-trimethyltridecanoate was the main component to attract females (Borges et al. 1998a). Costa et al. (2000) carried out a set of experiments that showed that the racemic mixture of methyl 2,4,6trimethyltridecanoate was efficiently attractive to females in laboratory bioassays. Methyl 2,6,10-trimethyltridecanoate has eight possible stereoisomers. The absolute configuration of methyl 2,6,10-trimethyltridecanoate was inferred by means of bioassays using the eight stereoisomers separately, which were synthesized by Mori \& Murata (1994). Costa et al. (2000) reported that females respond better to isomer $2 S, 6 R, 10 S$ than the other isomers when compared with a solvent (Fig. 3). In addition, they showed that one of the isomers $(2 \mathrm{R}, 6 \mathrm{~S}, 10 \mathrm{~S})$ did not attract the insects, and most of the insects responded to the solvent when this isomer was used as a stimulus (Fig. 3) suggesting a possible repellent action. However, the presence of this component in the racemic mixture did not have an antagonist effect. Borges et al. (1998b), using the racemic mixture of methyl 2,4,6trimethyltridecanoate, captured E. heros in field traps.

In the field, experiments were carried out in a soybean crop by placing lures with $10 \mu \mathrm{g}$ of racemic mixture of methyl 2,6,10-trimethyltridecanoate in traps (Borges et al. 1998b). Traps containing the racemic mixture caught a higher number of E. heros, along with another pentatomid, P. guildinii, when compared with a trap containing only the septum with solvent (Borges et al. 1998b). The racemic mixture in a lure formulation attracted $E$. heros in field conditions with a potential to be used in population monitoring (Borges et al. 1998b, 2007b, Laumann et al., 2007a).

Recently, Moraes et al. (2008b) carried out a simple study of $E$. heros that revealed the importance of understanding the physiology and the behaviour of stink bugs in order to identify the correct sex pheromone blend. When the insects were aerated with food (Phaseolus vulgaris pods), males of $E$. heros released all three components in the ratio reported by Zhang et al. (2003) during seven consecutive days. On the other hand, when the insects were kept in aeration without food, after $48 \mathrm{~h}$ they stopped releasing the main component of the sex pheromone (methyl $2 S, 6 R, 10 S$-trimethyltridecanoate), and they released in higher quantities the first component of the blend, methyl $(2 E, 4 Z)$-decadienoate.

\section{Thyanta perditor}

Males of $T$. perditor produce the ester methyl $2 E, 4 Z, 6 Z$ decatrienoate $((E 2, Z 4, Z 6)-10: \mathrm{COOMe})$ as the main sex pheromone component (Moraes et al. 2005a) (Table 2, compound 10). The same component was also identified in pheromone blend of the two neartic species Thyanta pallidovirens Stål and Thyanta custator acerra McAfee (Millar et al. 1997, McBrien et al. 2002) (Table 2, compound 7, 8 and 9). As in Nezara and Chinavia spp., Thyanta spp. have very similar blends, which suggests that closely related species of stink bugs share the same or similar blends as sex pheromones, with specificity possibly being due to different ratios of the compounds in the blend. GC analysis of the extracts of males showed a male-specific compound with a large and irregularly shaped peak, suggesting a thermally unstable compound (Fig. 4). Mass spectrometry analysis followed by high performance liquid chromatography (HPLC) suggested the presence of three conjugated unsaturations in the molecule, and a straight 10 -carbon chain. The presence of fragments at $\mathrm{m} / \mathrm{z} 105$ and 74 suggested a McLafferty rearrangement of a methyl ester, and along with the molecular weight of 180 , it appeared the compound was the same as identified for the other Thyanta species. Comparison of the GC retention time, peak shape and mass spectra of the unknown compound with standards of the $(2 E, 4 E, 6 E)-,(2 E, 4 Z, 6 E)-,(2 E, 4 E, 6 Z)$-. and $(2 E, 4 Z, 6 Z)$ isomers of methyl $(2,4,6)$-decatrienoate, confirmed that the compound produced by $T$. perditor is the ester methyl 
Table 2. Sex pheromone identified in stink bugs from Brazil: Eh - Euschistus heros; Nv - Nezara viridula; Pg - Piezodorus guildinii; Tp - Thyanta perditor, Tl - Tibraca limbativentris, and some worldwide species: Tca - Thyanta custator acerra, $\mathrm{Ph}$ Piezodorus hybneri. List obtained from studies of Moraes et al. (2005), Borges et al. (2006), Borges et al. (2007a) and Mcbrien et al. (2002).

\begin{tabular}{|c|c|c|c|c|}
\hline $\mathrm{N}^{0}$ & Compounds & Structure & Mass spectra & Species \\
\hline 1 & Methyl 2,6,10-tridecanoate & & $\begin{array}{l}270\left(\mathrm{M}^{+}, 3,7\right), 227(1,2), 199(1,4), \\
180(5,9) 157(14,2), 101(41,9), 88 \\
(100), 69(16,7), 55(30,3)\end{array}$ & Eh \\
\hline 2 & Methyl E 2,Z4- decadienoate & & $\begin{array}{l}182(17,8), 151(17.9), 139(7,0), \\
122(12,3), 111(100), 97(25.6), 81 \\
(92.3), 67(64.4), 55(33,0), 41(52.3)\end{array}$ & Eh \\
\hline 3 & $\begin{array}{l}\text { Methyl 2,6,10- } \\
\text { trimethyldodecanoate }\end{array}$ & & $\begin{array}{l}256(3,4), 203(1,2) 152(0,6), 119 \\
(10,2), 101(40,3), 88(100), 69 \\
(19,8), 55(41,6)\end{array}$ & Eh \\
\hline 4 & (Z)-8-Methyl hexadecenoate & & $\begin{array}{l}268\left(\mathrm{M}^{+}\right), 237(12), 236(14), 194 \\
(17), 152(14), 141(8), 137(11), \\
123(17), 110(23), 97(41), 87(48), \\
74(75), 69(61), 43(56), 55(100), \\
41(75)\end{array}$ & $\mathrm{Ph}$ \\
\hline 5 & (R)-15-Hexadecanolide & & $\begin{array}{l}254\left(\mathrm{M}^{+}\right), 236(17), 210(10), 194 \\
(7), 192(9), 152(11), 125(13), 111 \\
(22), 105(100), 97(41), 83(42), 71 \\
(32), 69(53), 43(54), 41(83)\end{array}$ & $\mathrm{Ph}$ \\
\hline 6 & $\begin{array}{l}(7 R)-(+)-\beta- \\
\text { Sesquiphellandrene }\end{array}$ & & $\begin{array}{l}204\left(\mathrm{M}^{+}, 33\right), 161(66), 133(47), 120 \\
(38), 109(33) 93(73), 77(36), 69 \\
(100), 55(17), 41(46)\end{array}$ & $\mathrm{Pg}, \mathrm{Ph}^{*}$ \\
\hline 7 & (7S)-(-)-Zingiberene & & $\begin{array}{l}204\left(\mathrm{M}^{+}, 11\right), 161(10) 119(97), 93 \\
(100), 77(31), 69(40), 56(14), 55 \\
(13), 41(49)\end{array}$ & Tca \\
\hline 8 & $\begin{array}{l}(7 S)-(-)-\beta- \\
\text { Sesquiphellandrene }\end{array}$ & & $\begin{array}{l}204(15), 161(31), 133(26), 120 \\
(23), 93(53), 92(33), 91(47), 77 \\
(42), 69(100), 55(33), 41(99)\end{array}$ & Tca \\
\hline 9 & (7S)-(-)- $\alpha$-Curcumene & & $\begin{array}{l}202\left(\mathrm{M}^{+}, 26\right), 145(26), 132(74), \\
119(100), 105(48), 91(24), 83(19), \\
77(16), 69(21), 55(31), 41(53)\end{array}$ & Tca \\
\hline 10 & $\begin{array}{l}\text { Methyl } E 2, Z 4, Z 6 \text { - } \\
\text { decatrienoate }\end{array}$ & & $\begin{array}{l}180\left(\mathrm{M}^{+}, 63\right), 151(10), 149(11), \\
138(20), 137(11), 121(25), 120 \\
(18), 119(44), 111(18), 107(28), \\
105(30), 93(21), 91(100), 79(87), \\
77(38)\end{array}$ & Tp e Tca \\
\hline 11 & $\begin{array}{l}\text { cis-Z-Epoxybisabolene } \\
\text { trans-Z-Epoxy-bisabolene }\end{array}$ & & $\begin{array}{l}\text { cis-Z-EBA: } 220\left(\mathrm{M}^{+}, 2\right), 164(2), \\
\text { 133(20), } 131(8), 125(25), 121(18), \\
109(72), 107(41), 93(81), 81(55), \\
67(70), 55(43), 43(100) \\
\text { trans Z-EBA: } 220\left(\mathrm{M}^{+}, 2\right), 164(15), \\
131(35), 121(30), 109(95), 107 \\
(86), 93(100), 82(67), 67(76), 55 \\
(42), 43(94)\end{array}$ & $\begin{array}{l}\text { Chinavia sp. } \\
\text { Nezara sp. }\end{array}$ \\
\hline 12 & $\begin{array}{l}\text { (1R)-Zingiberenol, } \\
(1 S) \text {-Zingiberenol }\end{array}$ & & $\begin{array}{l}222\left(\mathrm{M}^{+}\right), 187207,204,189,179 \\
161,151,137,123,119,109,95,77 \\
69,55\end{array}$ & $\mathrm{Tl}$ \\
\hline
\end{tabular}

Ph did not have the absolute configuration of sesquiphellandre determined (Leal et al. 1998). 


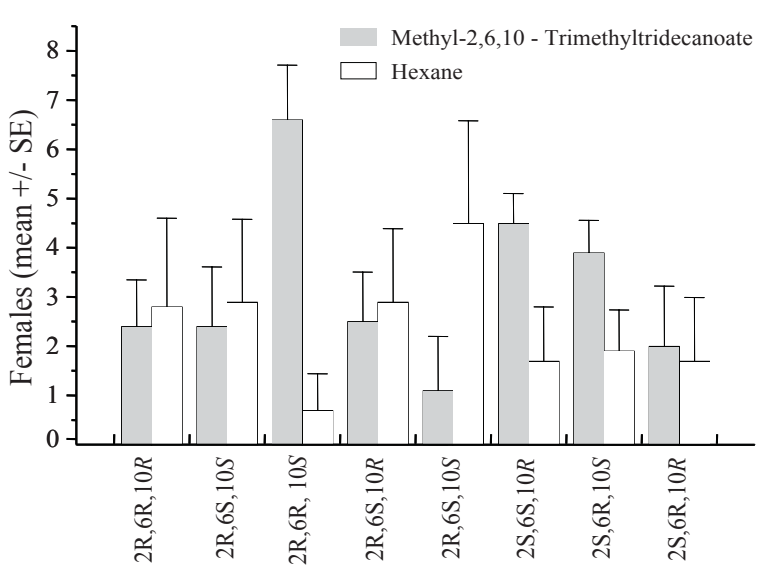

Fig. 3. Mean number of female $E$. heros responding to the eight stereoisomers of methyl 2,6,10-trimethyltridecanoate.

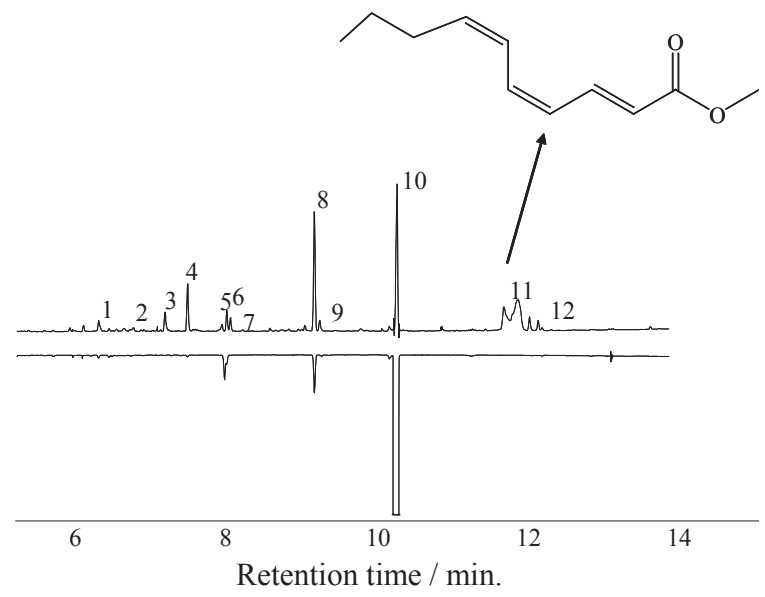

Fig. 4. Gas chromatograms of volatiles collected from live male (top) and female (bottom, inverted) T. perditor: $1, \alpha$-pinene; 2, $\beta$-pinene; $3, \alpha$-ocimene; 4, (E)-2-octenal; 5 , (E)-2-octen-1-ol; 6 , undecane; 7, nonanal; 8, dodecane; 9, (E)-2-decenal; 10, tridecane; 11, distorted peak from thermal decomposition of methyl (2E,4Z,6Z)-decatrienoate; 12, pentadecane.

$2 E, 4 Z, 6 Z$-decatrienoate. Bioassays in the laboratory showed that $4 \mu \mathrm{g}$ of the methyl $2 E, 4 Z, 6 Z$-decatrienoate was attractive to females of $T$. perditor (Moraes et al. 2005a). Traps baited with $1 \mathrm{mg}(E 2, Z 4, Z 6)-10$ : COOMe, protected and nonprotected from sunlight, were more efficient in capturing $T$. perditor than traps baited with the isomer $(E 2, E 4, Z 6)-10$ : COOMe, the pheromone of a Neartic pentatomid species, Plautia stali (Scott), and control traps. Additionally, traps baited with the sex pheromone captured a significantly higher number of insects than the sampling cloth technique, as well as some tachinid parasitoids of stink bugs. Results from field tests showed that the $(E 2, Z 4, Z 6)-10$ : COOMe has a great potential in monitoring populations of T. perditor, and this technique is more easily performed than the traditional cloth sampling (Laumann et al., unpublished).

\section{Piezodorus guildinii}

The Neotropical redbanded stink bug, $P$. guildinii is one species of the complex of stink bugs that are serious pests of soybean in Central and South America, especially in Brazil (Panizzi \& Rossi 1991). The first pheromone study of the genus Piezodorus was carried out by Leal et al. (1998), working with $P$. hybneri, a species distributed in Thailand, Korea, Taiwan, Japan and some regions of India and Australia (Shepard et al. 1983, Singh et al. 1989), which reportedly produces three compounds: $\beta$-sesquiphellandrene, $(R)$-15-hexadecanolide and methyl $(Z)$-8-hexadecenoate (Table 2, compounds 4, 5 and 7) in the proportion of 10 : 4: 1. Laboratory bioassays revealed that this blend is an aggregation pheromone, attracting both sexes.

Recently, Borges et al. (2007a) identified a new compound specific to males when gas chromatograms of extracts of volatiles collected from sexually mature virgin males and females were compared. This compound was not found in aerations of sexually immature females or males, and its retention time and mass spectra matched the sesquiterpene $\beta$-sesquiphellandrene. This identification was confirmed using an authentic standard, and the absolute configuration was determined as $(R)$ - $\beta$-sesquiphellandrene (Borges et al. 2007a). The quantitative analysis of 10 extracts obtained from volatile collection of 20 males resulted in a mean liberation of sexual pheromone of approximately 40 ng/24h. The bioassays showed that females of $P$. guildinii responded preferentially to $(7 R)$ - $\beta$-sesquiphellandrene, but the authors did not test the attraction power of the compound in the field, and the females also showed response to isomer (7S)- $\beta$-sesquiphellandrene.

\section{Tibraca limbativentris}

The Brazilian rice stalk stink bug T. limbativentris has three sesquiterpenoid isomers that were identified as compounds specific to males, called 1' $S$ zingiberenol, with a chemical structure of $\left(1 R S, 4 R S, 1^{\prime} S\right)$-4-(1',5'-dimethylhex4-enyl)-1-methylcyclohex-2-en-1-ol (Borges et al. 2006) (Table 2, compound 12). Because zingiberenol has three chiral centers (positions 1',1 and 4), there are eight isomers (four enantiomeric pairs of diastereomers). The non-selective synthesis produced two groups of isomers: zingiberenol I, containing the four isomers of $\left(1 R S .4 R S, 1^{\prime} R\right)-4-\left(1^{\prime}, 5^{\prime}-\right.$ dimethylhex-4-enyl)-1-methylcyclohex-2-en-1-ol; and zingiberenol II, containing the four isomers of $(1 R S .4 R S$, $\left.1^{\prime} S\right)$-4-(1',5'-dimethylhex-4-enyl)-1-methylcyclohex-2-en1-ol ). Females of $T$. limbativentris responded to zingiberenol II better than to zingibrenol I, suggesting that males produce the isomer 1'S zingiberenol (1RS. 4RS, 1'S)-4-(1',5'dimethylhex-4-enyl)-1-methylcyclohex-2-en-1-ol) (Borges et al. 2006).

\section{Conclusions and Future Directions}

Within the Heteroptera there are about 38,000 described 
species, and an estimated minimum of 25,000 undescribed species (Panizzi et al. 2000). Of the described species less than $1 \%$ have some type of semiochemical identified, usually only the defensive compounds (Table 3 ).

From the small sample of species presented here, it is clear that a fascinating diversity and complexity of chemical compounds are produced by these insects. The specificity provided by the stereochemistry of the sex attractant pheromones indicate a complex evolutionary scenario for chemical communication and behavioral ecology of pentatomid bugs and has biochemical implications. The enzymes responsible for biosynthesis of these compounds must be stereospecific, and the identification of the enzymes involved will provide information on stereo-specific catalysis, and may suggest precursors for development of stereo-specific methods of synthesis.

The defensive compounds produced by these insects are not as chemically interesting as the sex pheromones, but their biological roles are proving very important. Borges et al. (1993) showed that $(E)$-2-decenal and $(E)$-2-hexenal, both present in the allomones of several Brazilian pentatomids, have anti-microbial properties, inhibiting the germination and development of the entomopathogen $M$. anisopliae. Thus the presence or absence of these compounds could be very important in mediating the success of biological control efforts using pathogenic fungi. In aerations of $T$. limbativentris these components were not detected (Borges et al. 2006), nor were they found in preliminary MTG extracts (M.C.B. Moraes, unpublished data). Interestingly, in the field this species appears to suffer higher infection by $M$. anisopliae than $E$. heros, $N$. viridula or P. guildinii (SosaGómez \& Moscardi 1998, Da Silva Martins et al. 2004), species in which these compounds have been detected (Zarbin et al. 2000, Fucarino et al. 2004, Pareja et al. 2007). In future studies it could be interesting to look at how variation in MTG compounds affects mortality by fungi, both within and between species.
Defensive compounds also mediate interactions of the stink bugs with many different natural enemies. For certain species it has been shown that the egg parasitoids Trissolcus basalis Wollaston and Telenomus podisi Ashmead use compounds present in defensive blends to orient towards their hosts (Borges \&Aldrich 1994; Borges et al. 1997, 2003; Conti et al. 2004). Furthermore, T. basalis can distinguish between male and female blends of Nezara viridula (Colazza et al. 1999) and this could be influenced by the different composition of stink bugs MTG of males and females (Pareja et al. 2007). Additionally, some defensive compounds such as aldehydes can attract spiders and kelptoparasitic flies (Milichiidae and Chloropidae) (Aldrich \& Barros 1995) and (E)-2-decenal isolated from MTG of $N$. viridula, stimulates oviposition in the egg parasitoid, T. basalis (Mattiacci et al. 1993).

The diversity of pentatomid semiochemicals makes them an ideal system for studying the evolution of insect defence and of sex pheromone specificity. Blends of defensive compounds are species-specific, even though many of the compounds are shared between species (Pareja et al. 2007). Males and females also differ in their blends, and differ from nymphs. Nymphs are commonly gregarious, and this could be correlated with some of the chemical differences. Males are likely to be more exposed to natural enemies than females, since they produce the sex attractant pheromone and vibratory signals to attract the female (Moraes et al. 2005b) that can be exploited by natural enemies (Laumann et al. 2007b). Future work could determine whether this difference in exposure has had an effect on the defensive blends of males, and in resulting alarm behaviour. The pattern of differentiation of sex pheromones can also provide information on the ecological conditions that generate pheromone specificity. In particular the group of genera comprising Nezara and Chinavia could provide interesting insights into pheromone specificity, since their pheromones consist of isomers of $Z$-EBA in different ratios. For example C. ubica has a similar blend to the North American Chinavia species, while $C$.

Table 3. Number of species from different genera of Pentatomidae studied whose semiochemicals have been investigated. BR indicates the Brazilian species studied, "*” indicate the species which their sex pheromones were studied and laboratory bioassays or field tests were carried out to test the sex pheromone. "1" new classification of Acrosternum from the regions cited in this text is referred as Chinavia.

\begin{tabular}{|c|c|c|}
\hline Genus & Species studied & References \\
\hline Aelia & A. fieberi (Scott) & Tsuyuki et al. 1965 \\
\hline Apodiphus & A. amygdali (Germar) & Everton et al. 1974 \\
\hline Aspongopus & Aspongopus sp. & Prestwich 1976 \\
\hline Banasa & B. calva (Say), B. dimidiata (Say) & Aldrich et al. 2007 \\
\hline Biprorulus & B. bibax (Breddin) & $\begin{array}{c}\text { MacLeod et al. 1975; Oliver et al. 1992; James et } \\
\text { al. 1996, } 1994\end{array}$ \\
\hline Brochymena & B. quadripustulata (F.), Brochymena $\mathrm{sp.}$ & Blum 1961, Leskey \& Hogmire 2005 \\
\hline Caura & C. rufiventris (Germar) & Prestwich 1976 \\
\hline Chlorochroa & C. ligata $\left(\right.$ Say) ${ }^{*}$, C. sayi (Stål) ${ }^{*}$, C. uhleri $\left(\right.$ Stål) ${ }^{*}$ & Ho \& Millar 2001a, b, c \\
\hline Chinavia & 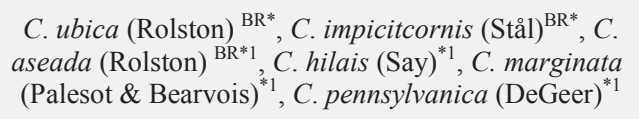 & Aldrich et al. 1993b, McBrien et al. 2001 \\
\hline
\end{tabular}


Table 3. Continuation.

\begin{tabular}{|c|c|c|}
\hline Genus & Species studied & References \\
\hline Coridius & C.janus (F.) & Gunawardena \& Herath 1991 \\
\hline Cosmopepla & C. bimaculata (Thomas) & Krall et al. 1999 \\
\hline Cyclopelta & C. siccifolia (Westwood) & Sagar et al. 2000 \\
\hline Delegorguella & D. lautus (Stål) & Prestwich 1976 \\
\hline Dichelops & D. melachantus (Dallas) ${ }^{\mathrm{BR}}$ & Marques et al. 2007, Pareja et al. 2007 \\
\hline Dolycoris & D. baccarum (L.) & Schildknecht 1964 \\
\hline Edessa & E. rufomarginata (DeGeer) & Howard \& Wiemer 1983, Howard 1987 \\
\hline Eocanthecona & E. furcellata (Wolff) & Ho et al. 2003 \\
\hline Erthesina & E. fullo (Thunberg) & Kou et al. 1989 \\
\hline Eurogaster & Eurogaster sp. & Schildknecht 1964 \\
\hline Eurydema & $\begin{array}{l}\text { E. oleraceum }(\text { L. })^{*}, \text { E. pulchrum (Westwood), E. rugosa } \\
\text { (Motschulsky), E. ventrale (Kolenati) }\end{array}$ & Ishiwatari 1974, 1976; Aldrich et al. 1995a, 1996b \\
\hline Euschistus & $\begin{array}{c}\text { E. conspersus (Uhler) }{ }^{*} \text {, E.heros }(\mathrm{F} .)^{\mathrm{BR}^{*}}, \text { E. ictericus }(\mathrm{L} .), \\
\text { E. obscurus, (Palisot \& Beavois), E. politus (Uhler), } \\
\text { E. servus (Say), E. tristigmus (Say) }\end{array}$ & $\begin{array}{c}\text { Aldrich et al 1991,1994, 1995, 2007; Borges et al. } \\
\text { 1994, Krupke 2001, Leskey, } 2005\end{array}$ \\
\hline Eysarcoris & E.parvus (Uhler) ${ }^{*}$ & Men et al. 1999 \\
\hline Graphosoma & G. rubrolineatum (Westwood) & Tsuyuki et al. 1965 \\
\hline Halyomorpha & H. halys (Stål) & Lee et al. 2002, Khrimian 2005, Aldrich et al. 2007 \\
\hline Lincus & L. malevolus (Roleston), L. spurcus (Roleston) & Nagnan et al. 1994 \\
\hline Mecidea & M. major (Sailer), M. minor (Ruckes) & Keaster et al. 1996 \\
\hline Murgantia & M. histrionica $(\mathrm{Hahn})^{*}$ & Aldrich et al. 1996 \\
\hline Nezara & $\begin{array}{c}\text { N. antennata }(\mathrm{Scott})^{*}, N \text {. viridula }(\mathrm{L} .)^{\mathrm{BR} *}, \\
N . \text { viridula smaragdula }(\mathrm{F} .)\end{array}$ & $\begin{array}{c}\text { Waterhouse et al. 1961, Tsuyuki et al. 1965, Baker } \\
\text { et al, 1987, Lockwood \& Story 1987, Aldrich et al. } \\
\text { 1989, Brezot et al. 1994, Borges } 1995\end{array}$ \\
\hline Oebalus & O.pugnax (F.) & Blum et al. 1960, Keaster et al. 1996 \\
\hline Oechalia & O. schellenbergii (Guérin-Meneville) ${ }^{*}$ & Aldrich et al. 1996a \\
\hline Oplomus & O. severus $(\text { Breddin })^{*}$ & Aldrich et al. $1986 \mathrm{a}$ \\
\hline Palomena & P. viridissima (Poda) & Schildknecht et al. 1964 \\
\hline Perillus & P. bioculatus (F.) & Aldrich et al. 1986a; Weissbecker et al. 1999, 2000 \\
\hline Piezodorus & $\begin{array}{c}\text { P. guildinii (Westwood) }{ }^{\mathrm{BR}^{*}}, \text { P. hybneri }(\text { Gmelin })^{*} \text {, } \\
\text { P.teretipes (Stål) }\end{array}$ & $\begin{array}{l}\text { Gilchrist et al. 1966; Leal et al. 1998; Borges et al. } \\
\text { 1999, 2007a; Zarbin et al. 2000; Endo et al. 2003; } \\
\text { Endo et al, 2006, Huh et al. } 2006\end{array}$ \\
\hline Plautia & P. stali (Scott) & Sugie et al. 1996 \\
\hline Podisus & $\begin{array}{l}\text { P. acutissimus (Stål), P. fretus (Olsen), P. maculiventris } \\
\text { (Say), P. nigrispinus (Dallas) }\end{array}$ & $\begin{array}{l}\text { Aldrich 1978, 1984a, b; Aldrich et al. 1986b; } \\
\text { Keaster et al. 1996; Sant' Ana \& Dickens } 1998\end{array}$ \\
\hline Poecilometis & P. strigatus (Westwood) & Waterhouse et al. 1961 \\
\hline Rhoecocoris & R.. sulciventris (Stål) & $\begin{array}{l}\text { Park \& Sutherland 1961, Waterhouse et al. 1961, } \\
\text { MacLeod et al. } 1975\end{array}$ \\
\hline Scotinophara & S. lurida (Burmeister) & Tsuyuki et al. 1965 \\
\hline Stiretrus & S. anchorago (F.) & Aldrich et al. 1986a, Kochansky et al. 1989 \\
\hline Thyanta & $\begin{array}{c}\text { T. accera }(\mathrm{McAtee})^{*},{\text { T. custator accera }(\mathrm{McAtee})^{*} \text {, }}^{\text {T. pallidovirens }(\text { Stål })^{*}, \text { T. perditor }(\mathrm{F} .)^{\mathrm{BR}}}\end{array}$ & $\begin{array}{l}\text { Keaster et al. 1996, Millar 1997, McBrien et al. } \\
\text { 2002, Moraes et al. 2005a, Aldrich et al. } 2007\end{array}$ \\
\hline Tibraca & T. limbativentris (Stål) ${ }^{\mathrm{BR} *}$ & Borges et al. 2006 \\
\hline Veterna & $V \cdot$ patula (Distant) & Prestwich 1976 \\
\hline Vitellus & V. insularis (Stål) & Smith 1974 \\
\hline
\end{tabular}


impicticornis shows a complete absence of the cis isomer. Understanding the mechanisms generating these differences is likely to be a rich area of evolutionary research, perhaps leading to new hypothesis on Pentatomidae phylogeny.

Two major difficulties in the study of insect semiochemicals is the unequivocal determination of behavioural activity, and the development of simple, low-cost synthetic procedures that make the use of semiochemicals economically viable and practical. Purification and structural elucidation are no longer the limiting factors with the improvement of analytical equipment. However it must be noted that insects can be much more sensitive to chemical substances than our analytical equipment. This is most clearly seen in the study of insect response to plant volatiles, where insects can detect changes that are invisible to us, even with the most advanced techniques (van Dam \& Poppy 2008).

Determination of biological activity requires rigorous testing of different behavioural circumstances to understand whether the chemical compound of interest is mediating the interaction being studied. Despite new methodologies to monitor behaviour (i.e. computational automatized systems of capture and analyses of insect behaviour), simple bioassays are often critical to highlight the importance of semiochemical. In addition, it is important to consider how feeding conditions can affect the resulting pheromone blend and activity (Moraes et al. 2008b). Determination of biological activity is complicated by the difficulty of rearing many species in the laboratory, and the resulting changes in behaviour and general biology, even under strict rearing conditions. We can never be certain that insects reared in the laboratory will behave in the same manner as the wild insects. However, use of field-collected insects is also not ideal, since we do not know each individual's semiochemical history, plus insect behaviour studies in the field are hard to conduct. Thus, by necessity, the only solution is to use a combination of chemical, laboratory and field studies for correct determination of biological activity. This highlights the importance of the interaction between biologists, chemists and biochemists in the study of chemical ecology.

\section{Acknowledgments}

We would like to thank Dr. Antônio Ricardo Panizzi for kindly inviting this review. We are grateful to Dr. Jeffrey R. Aldrich from the USDA-ARS - Invasive Insects Biocontrol \& Behavior Laboratory, Beltsville, MD, USA, for many discussions and comments provided during the preparation of the manuscript. Financial support by the Conselho Nacional de Desenvolvimento Científico e Tecnológico (CNPq), Fundação de Apoio à Pesquisa do DF (FAPDF), International Foundation for Science (IFS) and EMBRAPA (Empresa Brasileira de Pesquisa Agropecuária) is gratefully acknowledged.

\section{References}

Aldrich, J.R. 1988. Chemical ecology of the Heteroptera. Ann. Rev. Entomol. 33: 211238.
Aldrich, J.R., A. Khrimian \& M.J. Camp. 2007. Methyl 2,4,6decatrienoates attract stink bugs and tachinid parasitoids. J. Chem. Ecol. 33: 801-815.

Aldrich J.R., G.K. Waite, C. Moore, J.A. Payne, W.R. Lusby \& J.P. Kochansky. 1993a. Male-specific volatiles from nearctic and australasian true bugs (Heteroptera, Coreidae and Alydidae). J. Chem. Ecol. 19: 2767-2781.

Aldrich, J.R., H. Numata, M. Borges, F. Bin, G.K. Waite \& W.R. Lusby. 1993b. Artifacts and pheromone blends from Nezara spp. and other stink bugs (Heteroptera, Pentatomidae). Z. Naturforsch. Sect. C J. Biosci. 48: 73-79.

Aldrich, J.R., J.E. Oliver, G.K. Waite, C. Moore \& R.M. Waters. 1996a. Identification of presumed pheromone blend from Australasian predaceous bug, Oechalia schellenbergii (Heteroptera: Pentatomidae). J. Chem. Ecol. 22: 729-738.

Aldrich, J.R., J.E. Oliver, W.R. Lusby \& J.P. Kochansky. 1986a. Identification of male-specific exocrine secretions from predatory stink bugs (Hemiptera, Pentatomidae). Arch. Insect Biochem. Physiol. 3: 1-12.

Aldrich, J.R., J.E. Oliver, W.R. Lusby, J.P. Kochansky \& J.A. Lockwood. 1987. Pheromone Strains of the Cosmopolitan Pest, Nezara-Viridula (Hemiptera, Pentatomidae) J. Exp. Zool. 244: 171-175.

Aldrich, J.R., J.E. Oliver, W.R. Lusby, J.P. Kochansky \& M. Borges. 1994. Identification of male-specific volatiles from nearctic and neotropical stink bugs (Heteroptera, Pentatomidae). J. Chem. Ecol. 20: 1103-1111.

Aldrich, J.R., J.P. Kochansky \& C.B.Abrams. 1984a. Attractant for a beneficial insect and its parasitoids: pheromone of the predatory spined soldier bug, Podisus maculiventris (Hemiptera: Pentatomidae). Environ. Entomol. 13: 1031-1036.

Aldrich, J.R., J.W. Avery, C.J. Lee, J.C. Graf, D.J. Harrison \& F. Bin. 1996b. Semiochemistry of cabbage bugs (Heteroptera: Pentatomidae: Eurydema and Murgantia). J. Entomol. Sci. 31: 172-182.

Aldrich, J.R., M.C. Rosi \& F. Bin. 1995. Behavioral correlates for minor volatile compounds from stink bugs (Heteroptera: Pentatomidae). J. Chem. Ecol. 21: 1907-1920.

Aldrich, J.R., M.P. Hoffmann, J.P. Kochansky, W.R. Lusby, J.E. Eger \& J.A. Payne. 1991. Identification and attractiveness of a major pheromone component for nearctic Euschistus spp. stink bugs (Heteroptera: Pentatomidae). Environ. Entomol. 20: 477-483

Aldrich, J.R., M.S.Blum, H.A. Lloyd \& H.M. Fales. 1978. Pentatomid natural products: chemistry and morphology of the III-IV dorsal abdominal glands of adults. J. Chem. Ecol. 4: 161-172.

Aldrich, J.R \& T.M. Barros. 1995. Chemical attraction of male crab spiders (Araneae, Thomisidae) and kleptoparasitic flies (Diptera, Milichiidae and Chloropidae). J. Arachnol. 23: 212-214.

Aldrich, J.R. \& T.R Yonke. 1975. Natural-products of abdominal and metathoracic scent glands of coreoid bugs. Ann. Entomol. 
Soc. Am. 68: 955-960.

Aldrich, J.R., W.R. Lusby, B.E. Marron, K.C. Nicolaou, M.P. Hoffmann \& L.T. Wilson. 1989. Pheromone blends of green stink bugs and possible parasitoid selection. Naturwissenschaften. 76: 173-175.

Aldrich, J.R., W.R. Lusby \& J.P.Kochansky. 1986b. Identification of a new predaceous stink bug pheromone and its attractiveness to the eastern yellowjacket. Experientia 42: 583-585.

Aldrich, J.R., W.R. Lusby, J.P.Kochansky \& C.B. Abrams. 1984b. Volatile compounds from the predatory insect Podisus maculiventris (Hemiptera: Pentatomidae): male and female metathoracic scent glannd and female dorsal abdominal gland secretions. J. Chem. Ecol. 10: 561-568.

Alizadeh, B.H., S. Kuwahara,W.S. Leal, \& H-C. Men. Synthesis if the racemate of (Z)-exo- $\alpha$-Bergamotenal, a pheromone component of the White-spotted spined Bug, Eysarcoris parvus Uhler. Biosci. Biotechonol. Biochem. 66:1415-1418.

Ando, T., S. Inomata \& M. Yamamoto. 2004. Lepidopteran sex pheromones. In Chemistry of pheromones and other semiochemicals I. Topics in current chemistry 1 st ed.. Springer and Verlag, New York. 239 p.

Baker, R., M.Borges, N.G. Cooke \& R.H. Herbert. 1987. Identification and synthesis of (z)-(1's,3'r,4's)(-)-2-(3',4'epoxy-4'-methylcyclohexyl)-6-methylhepta-2,5-diene, the sex-pheromone of the southern green stinkbug, Nezara-viridula (L) J. Chem. Soc. Chem. Comm. 6: 414-416.

Blatt, S.E., J.H. Borden, H.D. Pierce, R. Gries \& G. Gries. 1998. Alarm pheromone system of the western conifer seed bug, Leptoglossus occidentalis. J. Chem Ecol. 24: 1013-1031.

Blum, M.S. 1961. The presence of 2-hexenal in the scent gland of the pentatomid Brochymena quadripustulata. Ann. Entomol. Soc. Am. 54: 410-412.

Blum, M.S., J.G. Traynham, J.B. Chidester \& J.D. Boggus. 1960. n-Tridecane and trans-2-heptenal in scent gland of the rice stink bug, Oebalus pugnax (F.) Science 132: 1480-1481.

Borges, M. 1995. Attractant compounds of the southern green stink bug, Nezara viridula (L.) (Heteroptera: Pentatomidae). An. Soc. Entomol. Bras. 24: 215-225.

Borges, M., F.G.V. Schmidt, E.R. Sujii, M.A. Medeiros, K. Mori, P.H.G. Zarbin \& J.T.B. Ferreira. 1998a. Field responses of stink bugs to the natural and synthetic pheromone of the Neotropical brown stink bug, Euschistus heros (Heteroptera: Pentatomidae). Physiol. Entomol. 23: 202-207.

Borges, M., J.G. Millar, R.A. Laumann \& M.C.B. Moraes. 2007 a. A male-produced sex pheromone from the neotropical redbanded stink bug, Piezodorus guildinii (W.). J.Chem.Ecol. 33: $1235-1248$.

Borges, M. \& J.R. Aldrich. 1992. Instar-specific defensive secretions of stink bugs (Heteroptera, Pentatomidae).Experientia 48: 893-896.

Borges, M. \& J.R Aldrich. 1994. An attractant pheromone for nearctic stink bug, Euschistus obscurus (Heteroptera: Pentatomidae): insigth into a neotropical relative. J. Chem. Ecol. 20: 1095-1101.

Borges, M., K. Mori, M.L.M. Costa \& E.R. Sujii. 1998b. Behavioural evidence of methyl-2,6,10-trimethyltridecanoate as a sex pheromone of Euschistus heros (Het., Pentatomidae).J. Appl. Entomol. 122: 335-338.

Borges, M., L.T. Ferreira, M.L.M. Costa, M.V. Scarpati, H.M. Santos \& R.T. Lourenço. 1997. Semioquímicos associados aos parasitóides Trissolcus basalis e Telenomus podisi, para controle dos percevejos Nezara viridula e Euschistus heros, praga da soja. Comunicado Técnico no 18 . Embrapa Recursos Genéticos e Biotecnologia, 6p.

Borges, M., M. Birkett, J.R. Aldrich, J.E. Oliver, M. Chiba, Y. Murata, R.A. Laumann, J.A. Barrigossi, J.A Pickett \& M.C.B. Moraes. 2006. Sex attractant pheromone from the rice stalk stink bug, Tibraca limbativentris Stal. J. Chem. Ecol. 32: 2749-2761.

Borges, M., P.H.G. Zarbin, J.T.B. Ferreira \& M.L.M. da Costa. 1999. Pheromone sharing: blends based on the same compounds for Euschistus heros and Piezodorus guildinii. J. Chem. Ecol. 25: 629-634.

Borges, M., R.A. Laumann, M.C.B. Moraes, C.S.S. Pires, E.R.Sujii, B.S.Correa Ferreira \& C.J. Ávila. 2007b. Armadilhas iscadas com formulação do feromônio sexual do percevejo marrom, Euschistus heros, para o monitoramento de percevejos praga da soja. Boletim de Pesquisa e Desenvolvimento 129, Embrapa Recursos Genéticos e Biotecnologia, Brasília. 18 pp.

Borges, M., S. Colazza, P. Ramirez-Lucas, K.R. Chauhan, M.C.B. Moraes, \& J.R. Aldrich. 2003. Kairomonal effect of walking traces from Euschistus heros (Heteroptera : Pentatomidae) on two strains of Telenomus podisi Hymenoptera: Scelionidae). Physiol. Entomol. 28: 349-355.

Borges, M., S.C.M. Leal, M.S. Tigano-Milani \& M.C.C. Valadares. 1993. Efeito do feromônio de alarme do percevejo verde, Nezara Viridula (L.) (Hemiptera: Pentatomidae), sobre o fungo entomopatogênico Metarhizium anisopliae (Metsch.) Sorok.. An. Soc. Entomol. Bras. 22: 505-512.

Brezot, P., C. Malosse, K. Mori \& M. Renou. 1994. Bisabolene epoxides in sex pheromone in Nezara viridula (L.) (Heteroptera: Pentatomidae): role of cis isomer and relation to specificity of pheromone. J. Chem. Ecol. 20: 3133-3147.

Bruni, R., J. Sant'Ana, J.R. Aldrich \& F. Bin. 2000. Influence of host pheromone on egg parasitism by scelionid wasps: comparison of phoretic and nonphoretic parasitoids. J. Insect Behav. 13: 165-172.

Cokl, A., M. Virant-Doberlet \& N. Stritih. 2000. The structure and function of songs emitted by southern green stink bugs from Brazil, Florida, Italy and Slovenia. Physiol. Entomol. 25: 196-205.

Colazza, S., G. Salerno \& E. Wajnberg. 1999. Volatile and contact chemicals released by Nezara viridula (Heteroptera: Pentatomidae) have a kairomonal effect on the egg parasitoid Trissolcus basalis (Hymenoptera: Scelionidae). Biol. Control. 16: 310-317. 
CONAB, 2007. Seguimento da Campanha Brasileira de Grãos: Décima Primeira Pesquisa, Agosto de 2007 / Companhia Nacional de Abastecimento. Brasília, Conab, 29p.

Conti, E., G. Salerno, F. Bin \& S.B.Vinson. 2004. The role of host semiochemicals in parasitoid specificity: a case study with Trissolcus brochymenae and Trissolcus simoni on pentatomid bugs. Biol. Control 29: 435-444.

Costa, M.L.M., M. Borges \& E.F. Vilela. 2000. Effect of srereoisomers of the main component of the sex pheromone of Euschistus heros (F.) (Heteroptera: Pentatomidae) in the attactiveness of female. An. Soc. Entomol. Bras. 29: 413-422.

Da Silva Martins, J.F., M. Botton, J.J. Carbonari, E.D. Quintela. 2004. Eficiência de Metarhizium anisopliae no controle do percevejo-do-colmo, Tibraca limbativentris (Heteroptera: Pentatomidae) em lavoura de arroz irrigado. Ciência Rural 34: 1681-1688.

Dicke, M. \& M.W. Sabelis. 1988. Infochemical terminology: based on cost-benefit analysis rather than origin of compounds? Funct. Ecol. 2: 131-139.

Drijfhout, F.P., A.T. Groot, M.A. Posthumus, T.A. van Beek \& A. De Groot. 2002. Coupled gas chromatographicelectroantennographic responses of Lygocoris pabulinus (L.) to female and male produced volatiles. Chemoecology. 12: 113-118.

Endo, N., T. Wada \& M. Chiba. 2003. An attractant for Piezodorus hybner (Heteroptera: Pentatomidae) contained in the aggregation pheromone of Riptortus clavatus (Heteroptera: Alydidae). Kyushu Plant Prot. Res. 49: 88-91.

Everton, I.J., D.E. Games \& B.W. Staddon. 1974. Composition of scents from Apodiphus amygdali. Ann. Entomol. Soc. Am. 67: $815-816$.

Farine J.P., O. Bonnard, R. Brossut \& J.L. Le Quere. 1992. Chemistry of pheromonal and defensive secretions in the nymphs and the adults of Dysdercus-cingulatus Fabr (Heteroptera, Pyrrhocoridae). J. Chem. Ecol. 18: 65-76.

Fiaboe, M.K., A. Chabi-Olaye, S. Goundu, H. Smith, C. Borgemesister \& F. Schulthess. 2003. Sesamia calamitis calling behavior and its role in host finding of egg parasitois Telenomus busseolae, Telenomus isis and Lathromeris ovicida. J. Chem. Ecol. 29: 921-929.

Fucarino A., J.G. Millar, J.S. McElfresh \& S. Colazza. 2004. Chemical and physical signals mediating conspecific and heterospecific aggregation behavior of first instar stink bugs J. Chem. Ecol. 30: 1257-1269.

Gilchrist, T.L., F. Stansfield \& J.L. Cloudsley-Thompson. 1966. The odoriferous principle of Piezodorus teretipes (Stal) (Hemiptera: Pentatomoidae). Proc. R. Entomol. Soc. 41: 55-56.

Gilby, A.R. \& D.F. Waterhouse. 1967. Secretion from lateral scent glands of the green vegetable bug Nezara viridula. Nature, 216: 90-91.

Gunawardena, N.E. \& H.M.W.K.B. Herath. 1991. Significance of medium chain $\mathrm{n}$ alkanes as accompanying compounds in hemipteran defensive secretions: An investigation based on the defensive secretion of Coridius janus. J. Chem. Ecol. 17: 2449-2458

Ho, H.-Y. \& J.G. Millar. 2001a. Identification and synthesis of male-produced sex pheromone components of the stink bugs Chlorochroa ligata and Chlorochroa uhleri. J. Chem. Ecol. 27: 2067-2095

Ho, H.-Y. \& J.G. Millar. 2001b. Identification and synthesis of a male-produced sex pheromone from the stink bug Chlorochroa sayi. J. Chem. Ecol. 27: 1177-1201.

Ho, H.-Y. \& J.G. Millar. 2001c. Compounds in metathoracic glands of adults and dorsal abdominal glands of nymphs of the stink bugs, Chlorochroa uhleri, C. sayi, and C. ligata (Hemiptera: Pentatomidae). Zool. Stud. 40: 193-198.

Ho, H.-Y., R. Kou \& H.K. Tseng. 2003. Semiochemicals from the predatory stink bug Eocanthecona furcellata (Wolff): components of metathoracic gland, dorsal abdominal gland, and sternal gland secretions. J. Chem. Ecol. 29: 2101-2114.

Howard, J.J. 1987. Biological activity of the secretion of Edessa rufomarginata, Neotropical pentatomid. Rev. Biol. Trop. 35: 139-141.

Howard, J.J. \& D.F. Wiemer. 1983. The defensive secretion of Edessa rufomarginata. Naturwissenschaften 70: 202-203.

Huh, H.S., K.H. Park, H.Y. Choo \& G.C. Park. 2006. Attraction of Piezodorus hybneri to the aggregation pheromone components of Riptortus clavatus. J. Chem. Ecol. 32: 681-691.

Ishiwatari, T. 1974. Studies on the scent of stink bugs (Hemiptera: Pentatomidae). I. Alarm pheromone activity. Appl. Entomol. Zool. 9: 153-158.

Ishiwatari, T. 1976. Studies on the scent of sink bugs (Hemiptera: Pentatomidae) II. Agregation pheromone activity. Appl. Entomol. Zool. 11: 38-44.

James, D.G., K. Mori, J.R. Aldrich \& J.E. Oliver. 1994. Flightmediated attraction of Biprorulus bibax Breddin (Hemiptera: Pentatomidae) to natural and synthetic aggregation pheromone. J. Chem. Ecol. 20: 71-80.

James, D.G., R. Heffer \& M. Amaike. 1996. Field attraction of Biprorulus bibax Breddin (Hemiptera: Pentatomidae) to synthetic aggregation pheromone and $(E)$-2-hexenal, a pentatomid defense chemical. J. Chem. Ecol. Ecol. 22: 16971708.

Khrimian, A. 2005. The geometric isomers of methyl 2,4,6decatrienoate, including pheromones of at least two species of stink bugs. Tetrahedron 61: 3651-3657.

Keaster, A.J., J.A. Grundler, W.S. Craig \& M.A. Jackson. 1996. Noctuid moths and other insects captured in wing-style traps baited with black cutworm (Lepidoptera: Noctuidae) pheromone on offshore oil platforms in the Gulf of Mexico, 1988-1991. J. Kansas Entomol. Soc. 69: 17-25.

Kochansky, J., J.R. Aldrich \& W.R. Lusby. 1989. Synthesis and pheromonal activity of 6,10,13-trimethyl-1-tetradecanol for predatory stink bug, Stiretrus anchorago (Heteroptera: Pentatomidae). J. Chem. Ecol. 15: 1717-1728. 
Kou, R., D.S. Tang \& Y.S. Chow. 1989. Alarm pheromone of pentatomid bug, Erthesina fullo Thunberg (Hemiptera: Pentatomidae). J. Chem. Ecol. 15: 2695-2702.

Krall, B.S., R.J. Bartelt, C.J. Lewis \& D.W. Whitman. 1999. Chemical defense in the stink bug Cosmopepla bimaculata. J. Chem. Ecol. 25: 2477-2494

Krupke, C.H., J.F. Brunner, M.D. Doerr \& A.D. Kahn. 2001. Field attraction of the stink bug Euschistus conspersus (Hemiptera: Pentatomidae) to synthetic pheromone baited host plants. J. Econ. Entomol. 94: 1500-1505.

Laumann, R. A., M. Borges, M.C.B. Moraes, C.S.S. Pires, E.R. Sujii, B.S. Correa-Ferrreira \& C.J. Ávila. 2007a. Formulação do feromônio sexual do percevejo-marrom Euschistus heros: eficiência de atração, vida útil e raio de ação. Boletim de Pesquisa e Desenvolvimento 198, Embrapa Recursos Genéticos e Biotecnologia, Brasília. 17p.

Laumann, R. A., M.C.B Moraes, A. Cokl, M. Borges. 2007b. Eavesdropping on the sexual vibratory communication of stink bugs (Hemiptera: Pentatomidae) by the egg parasitoid Telenomus podisi. Anim. Behav. 73: 637-649.

Leal, W.S., S. Kuwahara, X.W. Shi,.H. Higuchi, C.E.B. Marino, M. Ono \& J. Meinwald. 1998. Male-released sex pheromone of the stink bug Piezodorus hybneri. J. Chem. Ecol. 24: 18171829.

Lee, K.C., C.H. Kang, D.W. Lee, S.M. Lee, C.G. Park \& H.Y. Choo. 2002. Seasonal occurrence trends of hemipteran bug pests monitored by mercury light and aggregation pheromone traps in sweet persimmon ochards. Korean J. Appl. Entomol. 41: 233-238.

Leskey, T.C. \& H.W. Hogmire. 2005. Monitoring stink bugs (Hemiptera: Pentatomidae) in mid-Atlantic apple and peach orchards. J. Econ. Entomol. 98: 143-153.

Lockwood J.A. \& R.N. Story 1985. Bifunctional pheromone in the 1st instar of the southern green stink bug, Nezara-viridula (1) (Hemiptera, Pentatomidae) - its characterization and interaction with other stimuli. Ann. Entomol. Soc. Am. 78: 474-479.

Lockwood, J.A. \& R.N. Story. 1987. Defensive secretion of the southern green stink bug (Hemiptera, Pentatomidae) as an alarm pheromone. Ann. Entomol. Soc. Am. 80: 686-691.

Lusby, W.R. \& J.P. Kochansky. 1986. Identification of male-specific exocrine secretions from predatory stink bugs (Hemiptera, Pentatomidae). Arch. Insect Biochem. Physiol. 3: 1-12.

MacLeod, J.K., I. Howe, J. Cable, J.D. Blake, J.T. Baker \& D. Smith. 1975. Volatile scent gland components of some tropical Hemiptera. J. Insect Physiol. 21: 1219-1224. Marques, F. A., E. P. Wendler, B. H. L. N. Sales Maia, M. U. Ventura \& I.C. Arruda-Gatti, 2007. Identification of defensive compounds in metathoracic glands of adults of the stink bug Dichelops melacanthus (Hemiptera: Pentatomidae). J. Braz. Chem. Soc. 18: $1242-1246$.

Mattiacci, L., S.B. Vinson, H.J. Williams, J.R. Aldrich \& F. Bin. 1993. A long range attractant kairomone for egg parasitoid Trissolcus-basalis, isolated from defensive secretion of its host, Nezara-viridula. J. Chem Ecol. 19: 1167-1181.
McBrien, H.L. \& J.G. Millar. 1999. Pheromones of phytophagous true bugs, p. 277-304. In J. Hardie \& A.K. Minks (eds.), Phytophagous bugs in pheromones of non-Lepidopteran insects associated with agricultural plants, CABI Publishing, 466p.

McBrien, H. L., J. G. Millar, L. Gottlieb, X. Chen \& R. E. Rice, 2001. Male produced sex attractant pheromone of the green stink bug, Acrosternum hilare (Say). J. Chem. Ecol. 27: 18211839.

McBrien, H.L., J.G. Millar, R.E. Rice, J.S. McElfresh, E. Cullen \& F.G. Zalom, 2002. Sex attractant pheromone of the redshouldered stink bug Thyanta pallidovirens: A pheromone blend with multiple redundant components. J. Chem. Ecol. 28: 1797-1818.

Miklas, N., M. Renou, I. Malosse \& C.Malosse. 2000. Repetibility of pheromone blend composition in individual males of the southern green stink bug, Nezara viridula. J.Chem. Ecol. 26: 2473-2485.

Millar, J.G. 1997. Methyl (2E,4Z,6Z)-deca-2,4,6-trienoate, a thermally unstable, sex specific compound from the stink bug Thyanta pallidovirens. Tetrahedron 38: 7971-7972.

Millar, J.G. \& K.F. Haynes. 2000. Methods in chemical ecology, v.1, 2nd ed., Kluwer Academic Publishers, Massachusetts, 390p.

Moraes, M.C.B., J.G. Millar, R.A. Laumann, E.R. Sujii, C.S.S. Pires \& M. Borges. 2005a. Sex attractant pheromone from the neotropical red-shouldered stink bug, Thyanta perditor (F.) J. Chem. Ecol. 31: 1415-1427.

Moraes, M.C.B., M. Borges, M. Pareja, G. H. Vieira, F.T.P. De Souza Sereno \& R.A. Laumann. 2008b. Food and humidity affect sex pheromone ratios in the stink bug, Euschistus heros. Physiol. Entomol. 33: 43-50.

Moraes, M.C.B., M. Pareja, R.A. Laumann, C.B. Hoffmann-Campo \& M. Borges. 2008a. Response of the parasitoid Telenomus podisi to induced volatiles from soybean damaged by stink bug herbivory and oviposition J. Plant Interact. 3: 1742-1756.

Moraes, M.C.B., R.A. Laumann, A. Cokl \& M. Borges. 2005b. Vibratory signals of four Neotropical stink bug species. Physiol. Entomol. 30: 175-188.

Mori, K. \& N. Murata.1994. Synthesis of all eight stereoisomers of methyl 2,6,10 trimethyltridecanoate, the male-produced pheromone of the stink bugs, Euschistus heros and E. obscurus. Liebigs Ann. Chem. 1153-1160.

Nagnan, P., P. Cassier, M. Andre, J.F. Llosa \& D. Guillaumin. 1994. Fine structure and physicochemical analysis of the metathoracic scent glands of Lincus malevolus (Rolston) and L. spurcus (Rolston) (Heteroptera: Pentatomidae). Int. J. Insect Morphol. Embryol. 23: 355-370.

Oliver, J.E., J.R. Aldrich, W.R. Lusby, R.M. Waters \& D.G.James. 1992. A male produced pheromone of the spined citrus bug. Tetrahedron Lett. 33: 891-894.

Panizzi, A.R. 1997. Wild hosts of pentatomids: Ecological significance and role in their pest status on crops. Ann. Rev. Entomol. 42: 99-122.

Panizzi, A. R. \& C. E. Rossi. 1991. The role of Acanthospermum 
hispidum in the phenology of Euschistus heros and of Nezara viridula. Entomol. Exp. Appl. 59: 67-74.

Panizzi, A.R., J.E. Mc Pherson, D.G. James, M. Javahery \& R. M. McPherson. 2000. Stink bugs (Pentatomidae), p 421-474. In M.Shepard \& A.R. Panizzi (eds.) Heteroptera of economic importance. CRC Press, New York, 799p.

Pareja, M., M. Borges, R.A. Laumann \& M.C.B. Moraes. 2007. Inter- and intraspecific variation in defensive compounds produced by five neotropical stink bug species (Hemiptera: Pentatomidae). J. Insect Physiol. 53: 639-648.

Park, R.J. \& M.D. Sutherland, 1961. Volatile constituents of the bronze orange bug, Rhoecocoris sulciventris. Aust. J. Chem. 15: 172-174.

Pavis C., C. Malosse, P.H. Ducrot \& C. Descoins. 1994. Dorsal abdominal glands in nymphs of southern green stink bug, Nezaraviridula (1) (Heteroptera, Pentatomidae)-chemistry of secretions of 5 instars and role of $(E)$-4-oxo-2-decenal, compound specific to first instars. J. Chem. Ecol. 20: 2213-2227.

Peres, W.A.A. 2004. Aspectos bioecológicos e táticas de manejo dos percevejos Nezara viridula (Linnaeus), Euschistus heros (Fabricius) e Piezodorus guildinii (Westwood) (Hemiptera: Pentatomidae) em cultivo orgânico de soja. Ph.D. Tesis, Universidade Federal do Paraná, Curitiba 160p.

Prestwich, G.D. 1976. Composition of the scents of eight east African hemipterans. Nymph-adult chemical polymorphism in coreids. Ann. Entomol. Soc. Am. 69: 812-814.

Sagar, C.V., C. Janaiah \& E.R. Narender, 2000. Volatile constituents of metathoracic scent secretions of adult Cyclopelta siccifolia Westwood (Hemiptera: Pentatomidae). Entomologia. 25: $39-46$.

Sant 'Ana, J. \& J.C. Dickens. 1998. Comparative electrophysiological studies of olfaction in predaceous bugs, Podisus maculiventris and P. nigrispinus. J. Chem. Ecol. 24: 965-984.

Schildknecht, H., K. Holoubek, K.H. Weis \& H. Kramer. 1964. Defensive substances of the arthropods, their isolation and identification. Angew. Chem. Int. Ed. 3: 73-82.

Schwertner C.F. 2005. Filogenia e classificação dos percevejosverdes do grupo Nezara Amyot \& Serville (Hemiptera, Pentatomidae, Pentatominae). Ph.D. Tesis. Instituto de Biociências, Universidade Federal do Rio Grande do Sul, Porto Alegre, 238p.

Shepard, M., R.J. Lawn \& M.A. Schneider. 1983. Insects on grain legumes in Northern Australia. A survey of potential pests and their enemies. Univ. Queensland Press, St. Lucia, Australia, 81p.

Singh, O. P., K. J. Singh \& R. D. Thakur. 1989. Studies on the bionomics and chemical control of stink bug, Piezodorus rubrofasciatus Fabricius, a new pest of soybean in Madhya Pradesh. Ind. J. Plant Prot. 17: 81-93.
Smith, R.M. 1974. The defensive secretion of Vitellus insularis (Heteroptera: Pentatomidae). N.Z. J. Zool. 1: 375-376.

Sosa-Gomez, D.R. \& F. Moscardi F. 1998. Laboratory and field studies on the infection of stink bugs, Nezara viridula, Piezodorus guildinii and Euschistus heros (Hemiptera; Pentatomidae) with Metarhizium anisopliae and Beauveria bassiana in Brazil. J. Invert. Pathol. 71: 115-120.

Sugie, H., M. Yoshida, K. Kawasaki, H. Noguchi, S. Moriya, K. Takagi, H. Fukuda, A. Fujiie, M. Yamanaka, Y. Ohira, T. Tsutsumi, K. Tsuda, K. Fukumoto, M. Yamashita \& H. Suzuki. 1996. Identification of the aggregation pheromone of the brown-winged green bug, Plautia stali Scott (Heteroptera: Pentatomidae). Appl. Entomol. Zool. 31: 427-431.

Tsuyuki, T., Y. Ogata, I. Yamamoto \& K.Shinmi. 1965. Stink bug aldehydes. Agric. Biol. Chem. 29: 419-427.

Vilela, E.F. \& T.M.C.Della Lucia. 2001. Feromônios de insetos, biologia, química e empregos no manejo de pragas, 2 ed. Holos, Ribeirão Preto, $155 \mathrm{p}$.

Vinson, S.B. 1985. The behaviour of parasitoids, p.417-469. In G.A. Kertut \& L.I. Gilbert (eds.), Comprehensive insect physiology, biochemistry and pharmacology. Pergamon Press, New York, 529p.

Zarbin, P.H.G., M. Borges, A.A. Dos Santosa, A.R.M. De Oliveira, F. Simonellia \& F.A. De Marques. 2000. Alarm pheromone system of stink bug Piezodorus guildinii (Heteroptera: Pentatomidae). J. Braz. Chem. Soc. 11: 424-428.

Zhang, A., M. Borges, J.R. Aldrich \& M.J.Camp. 2003. Stimulatory bug volatiles for the Neotropical Brown Stink Bug, Euschistus heros (F.) (Heteroptera: Pentatomidae). Neotrop. Entomol. 32: 713-717.

van Dam. N.M. \& G.M. Poppy, 2008. Why plant volatile analysis needs bioinformatics- detecting signals from noise in increasingly comples profiles. Plant Biol. 10: 29-37.

Waterhouse, D.F., D.A. Forss \& R.H. Hackman. 1961. Characteristic odour components of the scent of stink bugs. J. Insect Physiol. 6: 113-121.

Weissbecker, B., J.J.A. van Loon, M.A. Posthumus, H.J. Bouwmeester \& M. Dicke. 2000. Identification of volatile potato sesquiterpenoids and their olfactory detection by the two-spotted stinkbug Perillus bioculatus. J. Chem. Ecol. 26: 1433-1445.

Weissbecker, B., J.J.A. van Loon \& M. Dicke. 1999. Electroantennogram responses of a predator, Perillus bioculatus, and its prey, Leptinotarsa decemlineata, to plant volatiles. J. Chem. Ecol. 25: 2313-2325.

Received 29/II/08. Accepted 15/IX/08. 